\title{
The South Lilly \#4 Site (41UR279), Upshur County, Texas
}

Timothy K. Perttula

Heritage Research Center, Stephen F. Austin State University

Bo Nelson

Heritage Research Center, Stephen F. Austin State University

Mark Walters

Heritage Research Center, Stephen F. Austin State University

LeeAnnaa Schniebs

Follow this and additional works at: https://scholarworks.sfasu.edu/ita

Part of the American Material Culture Commons, Archaeological Anthropology Commons, Environmental Studies Commons, Other American Studies Commons, Other Arts and Humanities Commons, Other History of Art, Architecture, and Archaeology Commons, and the United States History Commons

Tell us how this article helped you.

This Article is brought to you for free and open access by the Center for Regional Heritage Research at SFA ScholarWorks. It has been accepted for inclusion in Index of Texas Archaeology: Open Access Gray Literature from the Lone Star State by an authorized editor of SFA ScholarWorks. For more information, please contact cdsscholarworks@sfasu.edu. 


\section{The South Lilly \#4 Site (41UR279), Upshur County, Texas \\ Creative Commons License \\ (c) $($ ) $(9)$}

This work is licensed under a Creative Commons Attribution-NonCommercial 4.0 International License 


\title{
THE SOUTH LILLY \#4 SITE (41UR279), UPSHUR COUNTY, TEXAS
}

\author{
Timothy K. Perttula, Bo Nelson, and Mark Walters, \\ with a contribution by LeeAnna Schniebs
}

\section{INTRODUCTION}

The South Lilly \#4 site was discovered in early 2003 by Bo Nelson during a survey of portions of the South Lilly Creek valley in Upshur County, Texas. During the course of his survey he recorded 13 prehistoric archeological sites on the north side of the valley, just upstream from the FM 556 crossing of South Lilly Creek. No archaeological sites had been previously known or recorded along this stretch of the valley, but his survey made it apparent that there was a high density of prehistoric sites along this creek, a tributary to Big Cypress Creek.

NeIson noted that several of these prehistoric sites had Caddo ceramic sherds, and/or were in locations where prehistoric Caddo habitation sites are often found in the northeastern Texas region. The South Lilly \#4 site is in one such setting, namely a prominent upland ridge and knoll ( 360 feet amsl) that projects southward into the South Lilly Creek valley (Figure 1), but is elevated well above any seasonal flooding along the creek and its broad floodplain (Figure 2). The landform was in pasture at the time, and surface exposure was virtually nil.

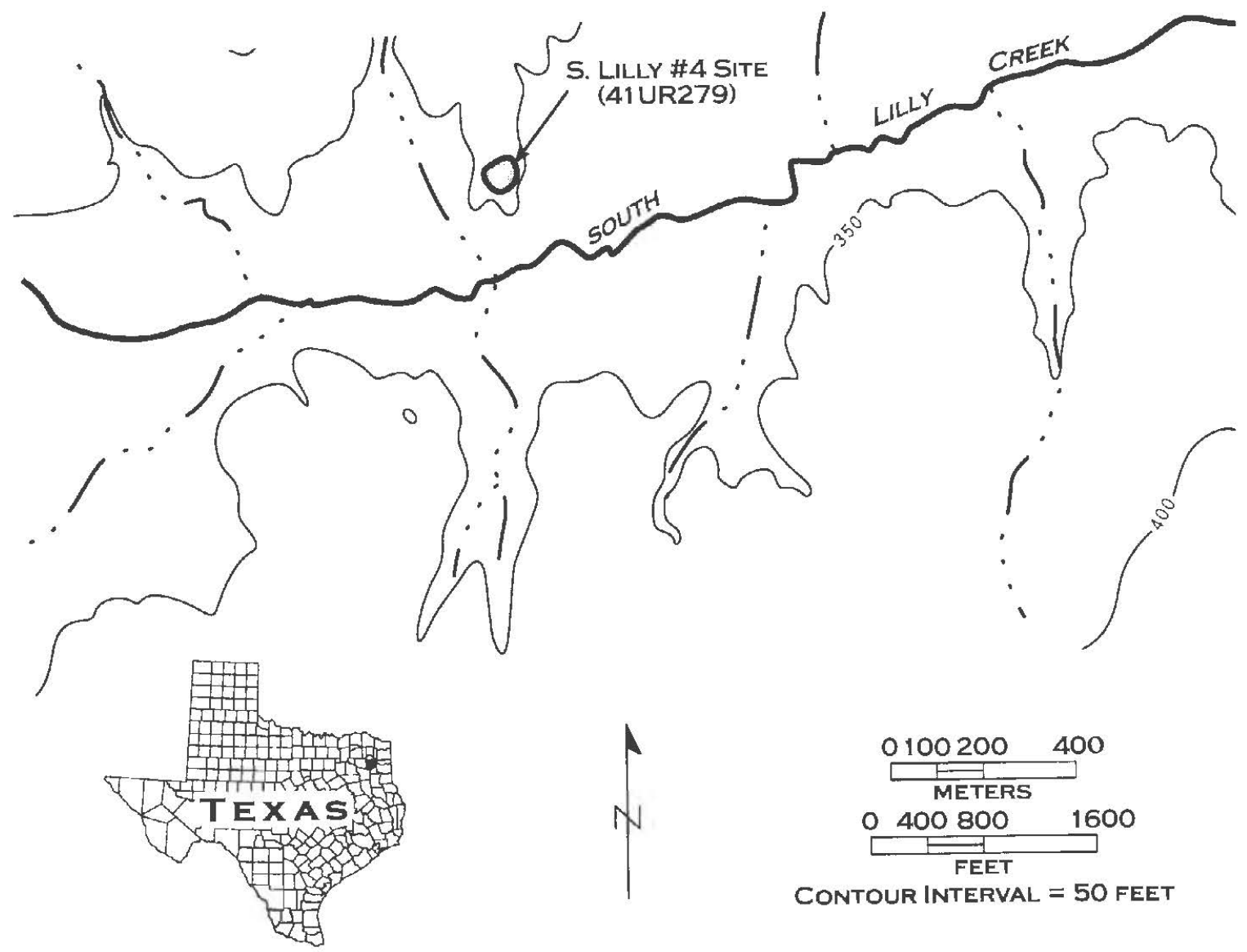

Figure I. The general setting of the South Lilly \#4 site (41UR279). 


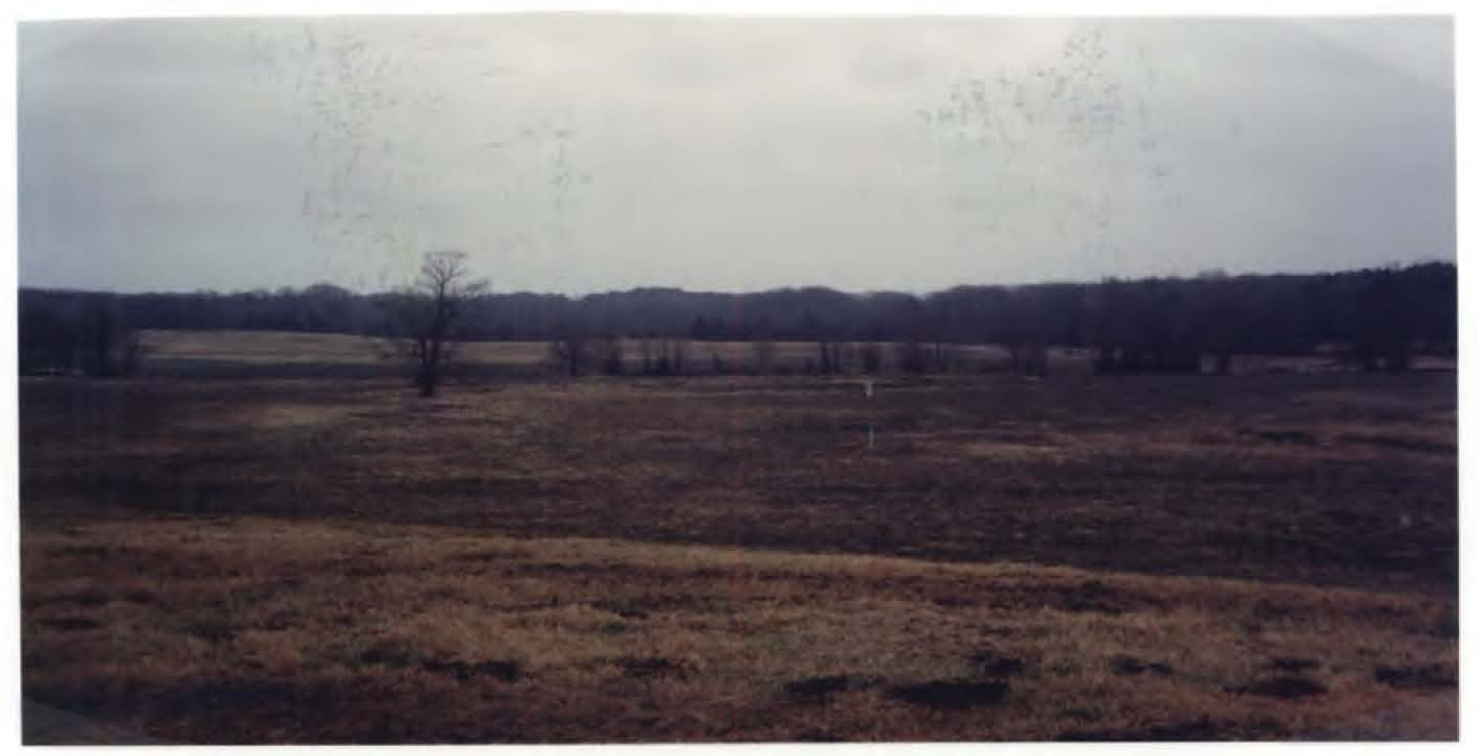

Figure 2. Looking south at the South Lilly Creek floodplain.

\section{ARCHAEOLOGICAL INVESTIGATIONS AT THE SOUTH LILLY \#4 SITE}

Three shovel tests (ST 1-3) were excavated in January 2003 on the prominent upland landform (Figure 3), and each of these had prehistoric Caddo pottery sherds, animal bone, charred nutshell, and lithic debris in a midden deposit that was between $43-46 \mathrm{~cm}$ in thickness. The Cuthbert fine sandy loam sediments at the site were about $64-79 \mathrm{~cm}$ thick overlying a strong brown clay.

Because there was a well-preserved prehistoric Caddo midden deposit at the site, in February 2003 we set out to conduct additional investigations here. Our purpose was primarily to assess the condition of the midden deposits, determine if there were other features preserved in and/or around the midden, obtain a controlled sample of associated artifacts from the archaeological deposits, and secure samples of charred plant remains and sediments to establish the age of the Caddo occupation here.

To that end, we first excavated four additional shovel tests (ST 4-7) to better establish the extent of the midden deposits (see Figure 3). Two of these shovel tests had midden deposits (ST 4 and ST 5), while the other two, at the southeastern end of the knoll, did not, although they did contain prehistoric ceramic sherds and lithic debris. The best preserved midden deposits appeared to be in and around ST 1, and thus we laid out a $1 \times 1$ $\mathrm{m}$ unit (Unit 1) about $90 \mathrm{~cm}$ east of it to gather more detailed information about these midden deposits. The unit was excavated in $10 \mathrm{~cm}$ arbitrary levels to a depth of $40 \mathrm{~cm}$ bs.

We expanded the hand-excavated unit to a $1 \times 2 \mathrm{~m}$ unit, adding on Unit 2 to the east of Unit 1 (see Figure 3), to obtain a better profile of the archaeological deposits, but also to increase our horizontal exposure in searching for features exposed in and below the midden deposits. As it turned out, two pit features were visible in the shovel-scraped floor of the unit, at $54 \mathrm{~cm}$ bs (see below). We excavated and screened four $10 \mathrm{~cm}$ thick arbitrary levels in Unit 2, taking fine-screen samples from $20-40 \mathrm{~cm}$ in both Unit 1 and 2 , and then shovelscraped the sediments to a depth (ca. $50-55 \mathrm{~cm}$ bs) where soil color contrasts were present; these color contrasts would aid in the identification of any features that extended below the midden. 


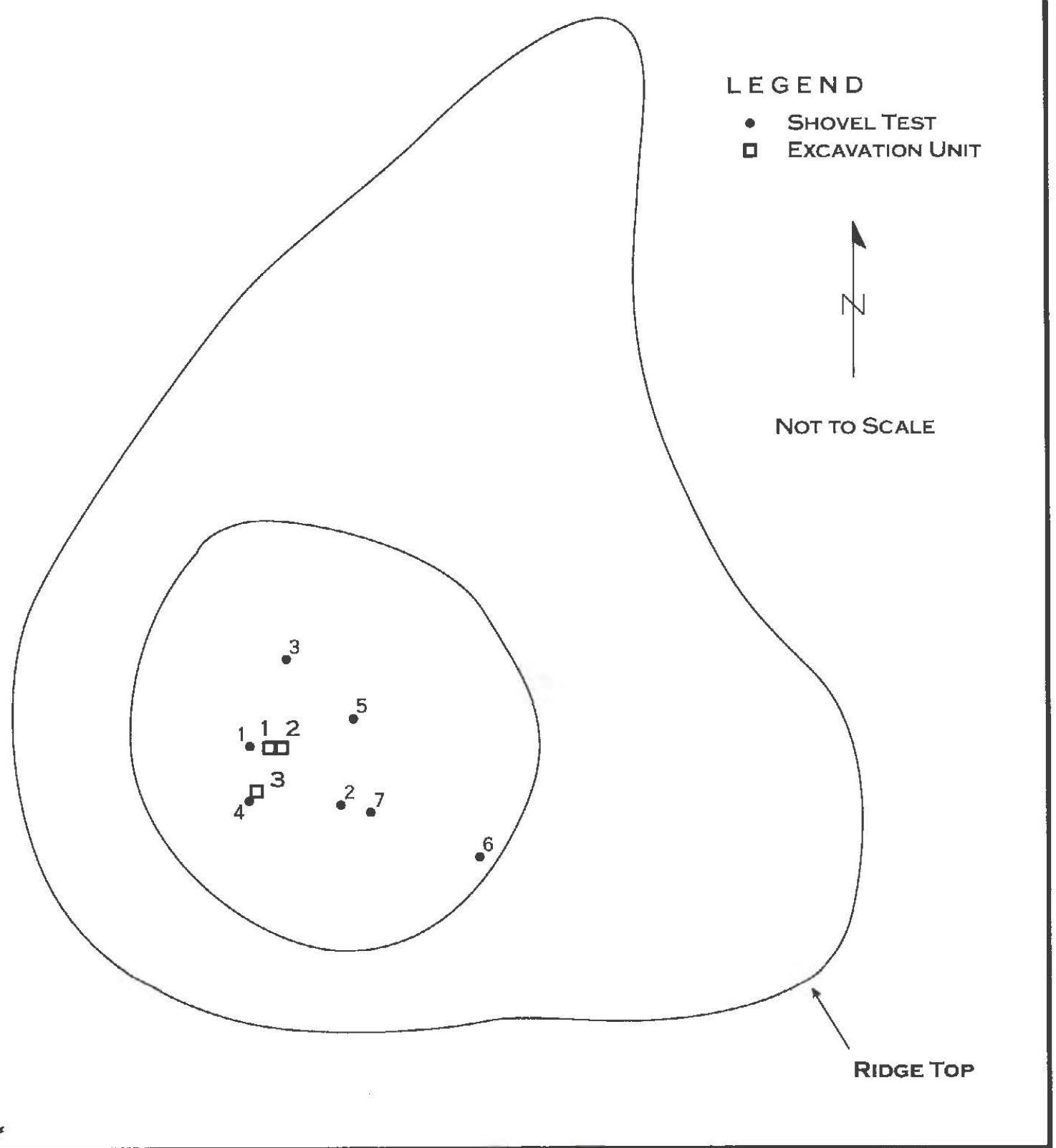

Figure 3. Location of shovel tests and $1 \times 1 \mathrm{~m}$ units at 41UR279.

Finally, we excavated a third $1 \times 1 \mathrm{~m}$ unit (Unit 3), placing it $3 \mathrm{~m}$ south of the southwestern corner of Unit 1 (Figure 4). This unit was also in the Caddo midden deposits.

The archaeological deposits at the South Lilly \#4 site occur in several sediment zones, principally Zone 2, the midden zone (Figure 5). Overlying the midden is a brown fine sandy loam (Zone 1) about $5-6 \mathrm{~cm}$ thick. The very dark brown fine sandy loam midden (with charcoal flecking) is ca. $35-40 \mathrm{~cm}$ thick in these units, and both Unit 1 and Unit 2 have a dark grayish brown fine sandy loam deposit (Zone 3 ) that extends to about $55 \mathrm{~cm}$ bs in some areas (Figure 6), but is otherwise discontinuous across the units; this zone of sediments lies atop Zone 4 . This zone is a yellowish-brown fine sandy loam $\mathrm{E}$ horizon, and extends to the B-horizon clay, which lay some $20 \mathrm{~cm}$ below the depth of our 


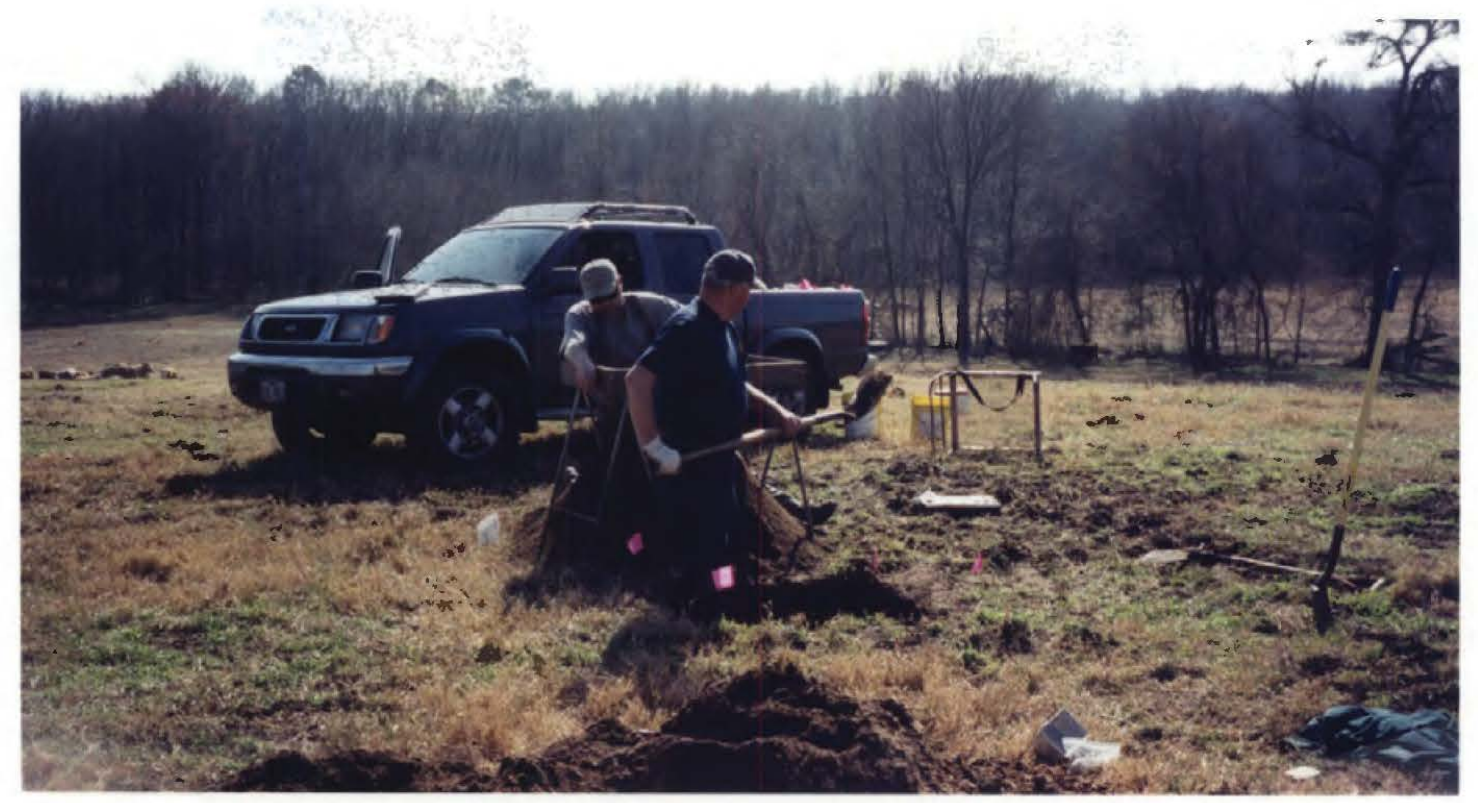

Figure 4. Excavations underway at the South Lilly \#4 site.

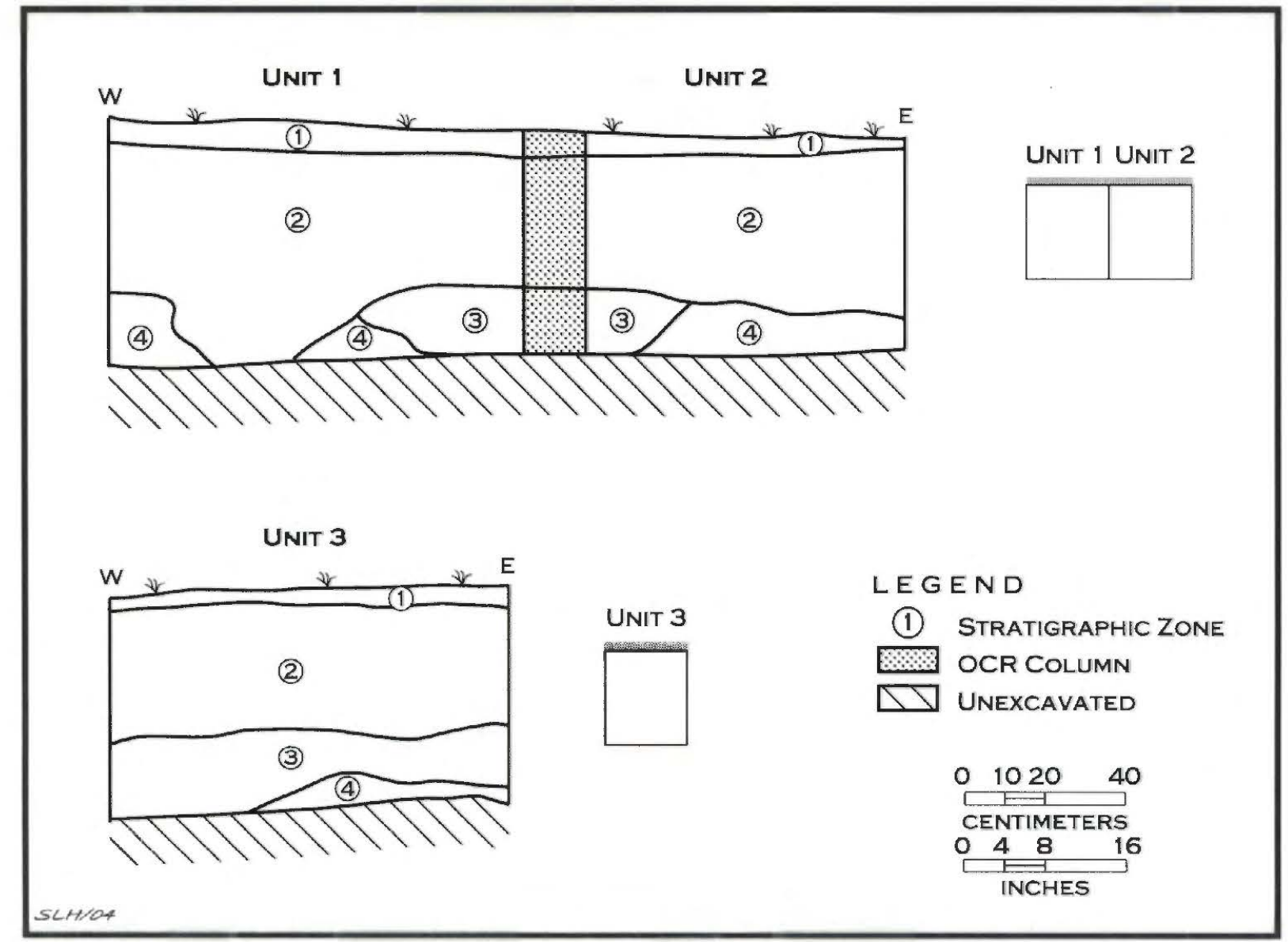

Figure 5. Profiles of Units $1 / 2$ and 3. 


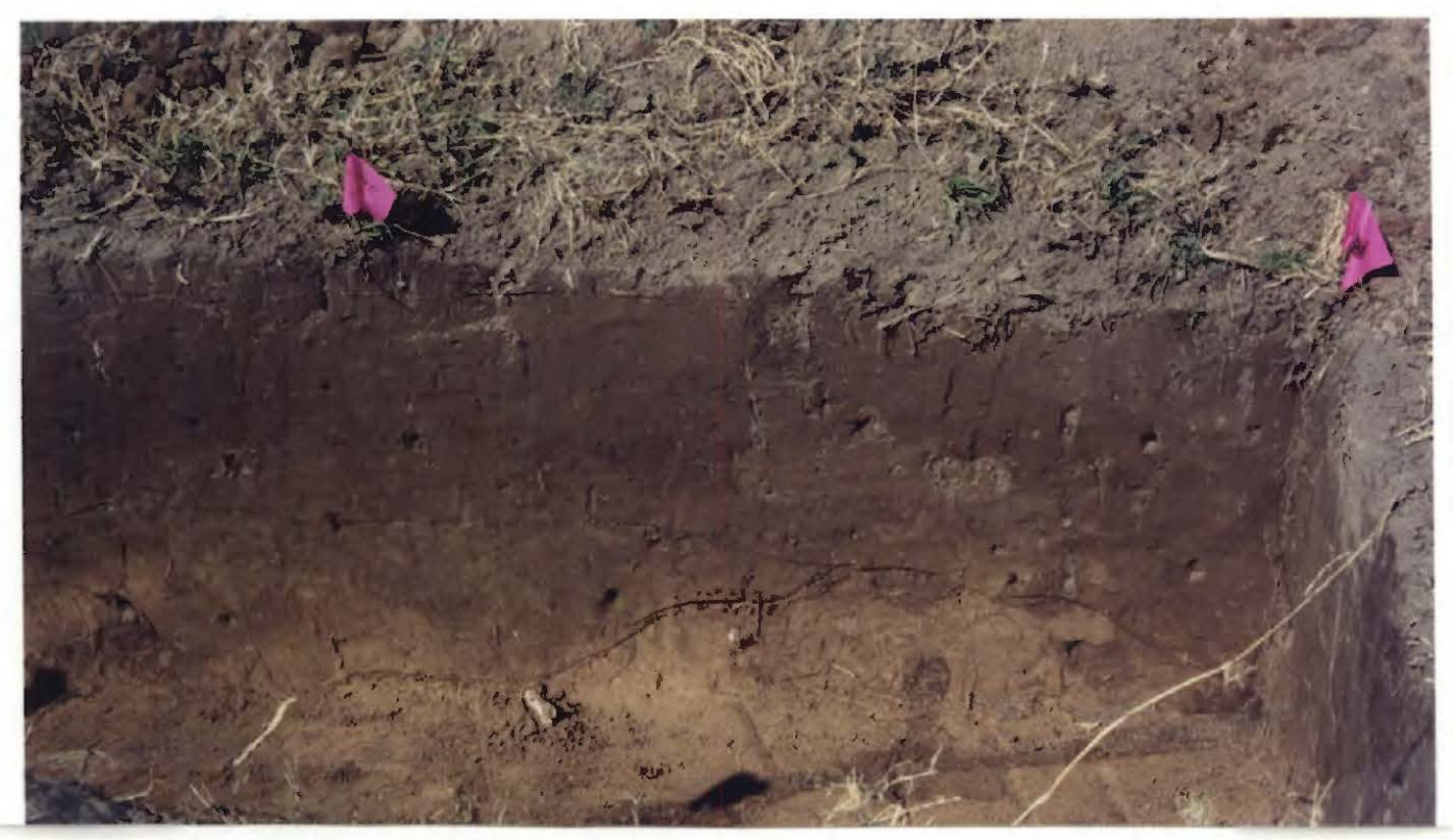

Figure 6. Unit $1 / 2$ profile, looking north.

excavations. Both features encountered in Unit 1 and Unit 2 became apparent when our excavations reached the contact of zones 2 and/or 3 with Zone 4 .

\section{Features}

Both features are apparently pits at least $50 \mathrm{~cm}$ in diameter (Figure 7), and both are characterized by a charcoal-flecked very dark brown fine sandy loam fill. Charred nutshells and a plain body sherd were noted in Feature 2 . The two features were exposed at $55 \mathrm{~cm}$ bs; they have yet to be excavated, however. Other probable features stains were visible in the floor of Units 1 and 2 (Figure 8).

\section{DATING OF THE SITE}

We obtained two radiocarbon dates from the Zone 2 midden deposits, both dates on charred hickory (Carya sp.) nutshells. The first date came from $20-30 \mathrm{~cm}$ bs in Unit 1 and 2 , and it included 103 charred nutshells weighing 4.5 grams. The conventional age of these nutshells in the upper part of the midden is A.D. $1490 \pm 50$ (Beta-183858), with a calibrated intercept of AD 1440 (see Appendix 1). At 1 sigma, the calibrated age range is AD 1420-1460, while at 2 sigma (with a 95\% probability) the calibrated age range is AD $1410-1500$.

The second date was from $30-40 \mathrm{~cm}$ bs in the same units; this is from the deepest part of the Zone 2 midden. The sample consisted of 126 charred nutshells weighing 4.6 grams. This sample has a conventional age of A.D. $1090 \pm 70$ (Beta-183859), and a calibrated intercept of AD 1190, some 250 years older than the calibrated date from the upper part of the midden deposits. The calibrated age range at 1 sigma is AD 1050-1260, with a AD 1020-1280 age range at 2 sigma.

Oxidizable Carbon Ratio (OCR) dates from the Zone 2 midden (see Appendix 2) in Unit 1 and 2 range from 409-555 years B.P., between A.D. 1395-1541. These basically overlap in time with the younger calibrated date obtained on charred hickory nutshells in the upper part of the midden itself. The one OCR date associated with a pedogenic event is AD 


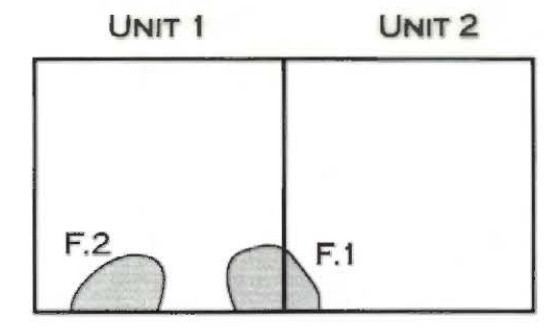

UNIT 3
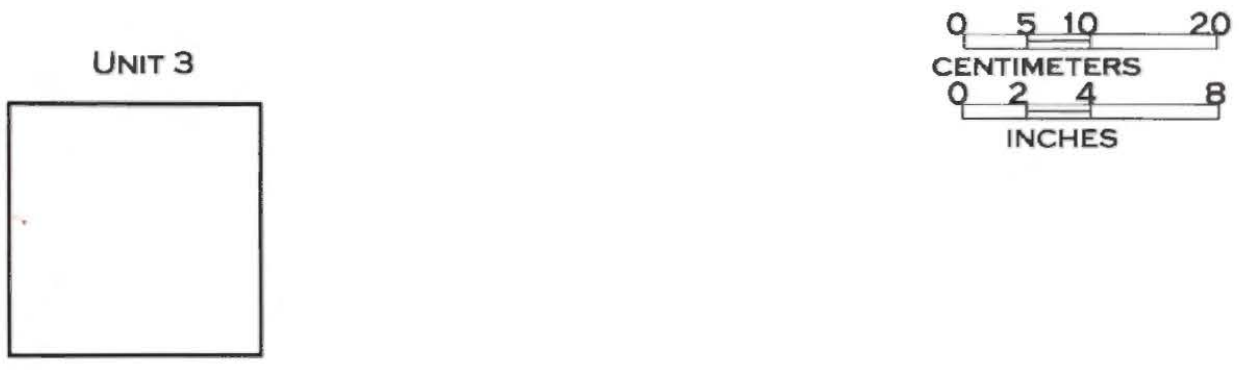

SLHIOF

Figure 7. Plan map of features in Units 1 and 2.

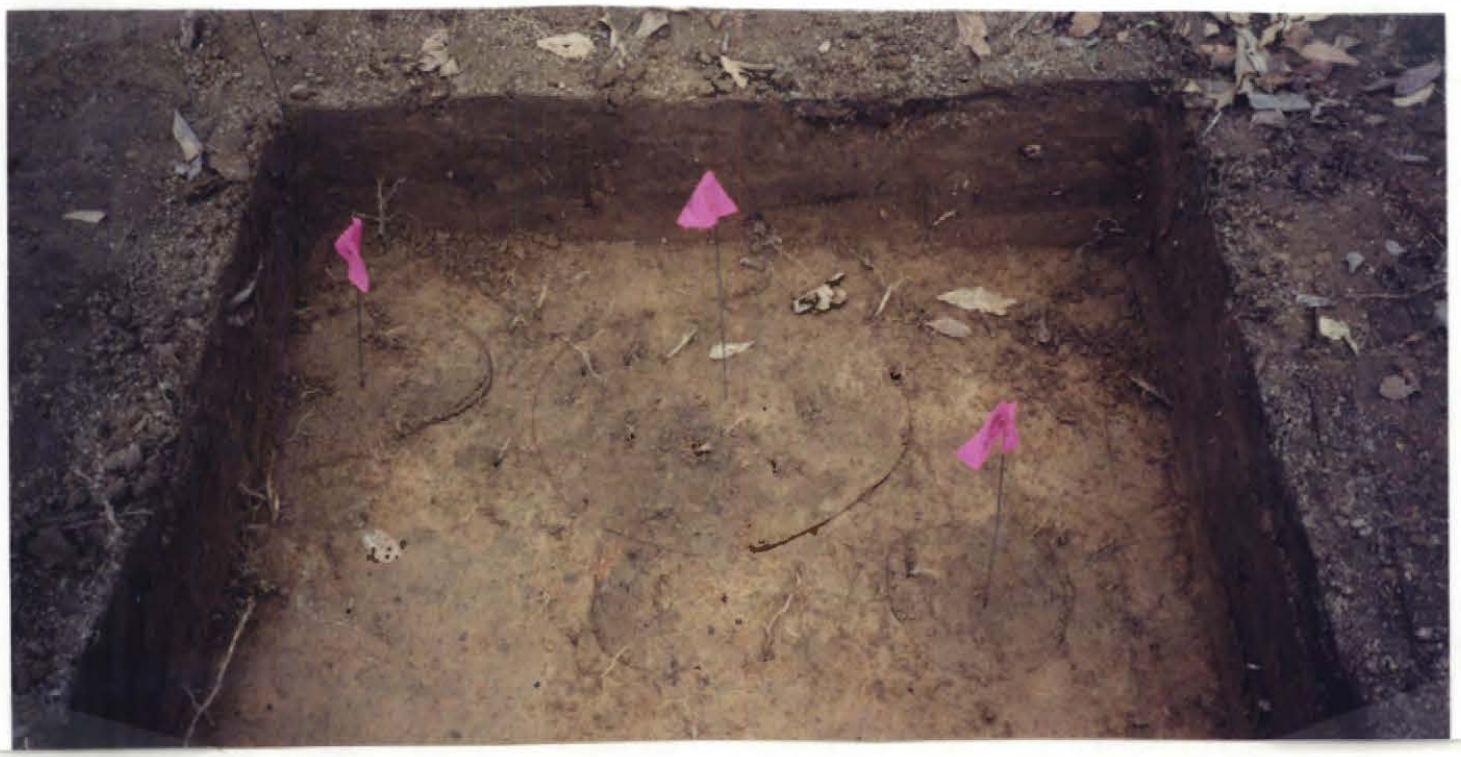

Figure 8. Marked stains (probable features) in Units 1 and 2. 
1379-1411 (the 18-20 cm bs), and may pertain to a significant period of deposition of the midden. OCR dates below the midden range from 658-709 years ago (A.D. 1241-1292) (see Appendix 2)

\section{ARTIFACTS FROM THE CADDO OCCUPATION}

A wide variety of prehistoric artifacts were recovered from the South Lilly \#4 site, including more than 300 plain and decorated pottery sherds, daub, burned clay, a few chipped stone tools, lithic debris, fire-cracked rock, animal bones, mussel shell fragments, and charred plant remains (hickory nutshells and wood charcoal pieces). We discuss in turn each of the different kinds of artifacts from the Caddo occupation, beginning with the plentiful ceramic sherds from fine ware and utility ware vessels.

\section{Ceramic Artifacts}

There are 309 sherds in the ceramic assemblage (Table 1), with about equal numbers in each of the three $1 \times 1 \mathrm{~m}$ units. The density of sherds in these excavations is between 80-89 sherds per square meter. There is an equal representation of plain and decorated sherds, and the plain to decorated sherd ratio is a low 0.99; this was our first hint that the South Lilly \#4 site was occupied in the Late Caddoan period (ca. A.D. 1400-1680), as plain to decorated sherd ratios less than 1.30 tend to be characteristic of Late Caddo ceramic assemblages in this part of northeastern Texas.

Table 1. Ceramic sherds from the South Lilly \#4 site.

\begin{tabular}{|c|c|c|c|c|c|c|}
\hline $\begin{array}{l}\text { Provenience } \\
\text { (cm bs) }\end{array}$ & $\begin{array}{l}\text { Decorated } \\
\text { Rim }\end{array}$ & $\begin{array}{l}\text { Decorated } \\
\text { Body }\end{array}$ & $\begin{array}{l}\text { Plain } \\
\text { rim }\end{array}$ & $\begin{array}{l}\text { Plain } \\
\text { body }\end{array}$ & $\begin{array}{l}\text { Plain } \\
\text { base }\end{array}$ & $\mathbf{N}$ \\
\hline Surface & & 1 & & & & 1 \\
\hline ST 1, 0-20 & & 1 & & 2 & 1 & 4 \\
\hline ST $1,20-40$ & & 1 & & 1 & & 2 \\
\hline ST $1,40-60$ & & & & 2 & & 2 \\
\hline ST $2,0-20$ & 1 & 2 & & & & 3 \\
\hline ST 2, 20-40 & & 1 & & & & 1 \\
\hline ST 3, 0-20 & & 2 & & 1 & & 3 \\
\hline ST 3, 20-40 & & & & 1 & & 1 \\
\hline ST 4, 0-20 & & 3 & & 3 & & 6 \\
\hline ST $4,20-40$ & 1 & 2 & & 3 & & 6 \\
\hline ST 5, 0-20 & & 2 & & 1 & & 3 \\
\hline ST $5,20-40$ & 1 & 2 & & 3 & 1 & 7 \\
\hline ST 6, 0-20 & & & & & 1 & 1 \\
\hline ST 6, 20-40 & & & & 2 & 1 & 3 \\
\hline ST 7, 20-40 & & 1 & & 2 & & 3 \\
\hline Sub-total & 3 & 17 & 0 & 21 & 4 & 45 \\
\hline Unit $1,0-10$ & 2 & 6 & 2 & 12 & & 22 \\
\hline Unit $1,10-20$ & 2 & 16 & & 18 & & 36 \\
\hline Unit 1, 20-30 & & 7 & & 9 & & 16 \\
\hline Unit 1, 20-30 FS & & & & 3 & & 3 \\
\hline Unit 1,3040 & & 7 & & 3 & & 10 \\
\hline
\end{tabular}


Table 1. Ceramic sherds from the South Lilly \#4 site, cont.

\begin{tabular}{lllllll}
\hline $\begin{array}{l}\text { Provenience } \\
\text { (cm bs) }\end{array}$ & $\begin{array}{l}\text { Decorated } \\
\text { Rim }\end{array}$ & $\begin{array}{l}\text { Decorated } \\
\text { Body }\end{array}$ & $\begin{array}{l}\text { Plain } \\
\text { rim }\end{array}$ & $\begin{array}{l}\text { Plain } \\
\text { body }\end{array}$ & $\begin{array}{l}\text { Plain } \\
\text { base }\end{array}$ & N \\
\hline $\begin{array}{l}\text { Unit 1, 30-40 FS } \\
\text { Unit 1, Fea. 2 }\end{array}$ & 1 & & & 1 & & 1 \\
Sub-total & 5 & 36 & 2 & 46 & & 89 \\
Unit 2, 0-10 & & 9 & & 5 & & 14 \\
Unit 2, 10-20 & 2 & 10 & & 16 & & 28 \\
Unit 2, 20-30 & 1 & 11 & 1 & 9 & & 1 \\
Unit 2, 30-30 FS & 1 & 1 & 1 & 6 & & 15 \\
Sub-total & 4 & 38 & 2 & 36 & & 80 \\
Unit 1/2 profile & & 4 & & 4 & & 8 \\
$\begin{array}{l}\text { Unit 3, 0-10 } \\
\text { Unit 3, 10-20 }\end{array}$ & 1 & 3 & & 3 & 1 & 8 \\
Unit 3, 20-30 & 2 & 22 & & 11 & 2 & 36 \\
Unit 3, 30-40 & & 5 & 1 & 11 & 1 & 26 \\
Unit 3, 40-50 & & 2 & 1 & 5 & 2 & 3 \\
Sub-total & 4 & 43 & 2 & 31 & 6 & 86 \\
\hline Total & 16 & 139 & 6 & 138 & 10 & 309 \\
\hline
\end{tabular}

The 155 decorated sherds are from both utility wares $(81 \%, \mathrm{n}=126)$ and fine wares $(19 \%, n=29)$ (Table 2). Among the utility wares, brushed sherds were by far the most common, accounting for almost $50 \%$ of these decorated sherds; brushed-incised sherds comprise another $8 \%$ of the utility wares. Most of the brushed decorations (and the brushed-incised sherds) were apparently confined to the vessel body, and only rarely were rims also brushed, given the high body to rim ratio (24.7:1) among the brushed sherds. The incised and punctated sherds, especially the punctated sherds, were from utility ware vessels likely to have been decorated on both the rim and body, although not necessarily with the same decorative element. Body to rim ratios for these groups of sherds are 13.5:1 and 1.5:1 (see Table 2).

Table 2. Decorated sherds from 41 UR279.

\begin{tabular}{lccc} 
Decorative Method & Decorated Rim & Decorated Body & N \\
\hline Utility wares & & & \\
Brushing & 3 & 74 & 77 \\
Incising & 2 & 27 & 29 \\
Brushed-Incised & - & 12 & 12
\end{tabular}


Table 2. Decorated sherds from 41UR279, cont.

Decorative Method Decorated Rim Decorated Body N

\begin{tabular}{llll}
\hline Punctated & 2 & 3 & 5 \\
Punctated-Incised & & 1 & 1 \\
Appliqued & & 2 & 2
\end{tabular}

Fine wares

$\begin{array}{llll}\text { Engraved } & 7 & 18 & 25 \\ \text { Red-slipped } & - & 4 & 4\end{array}$

Totals

14

141

155

The fine ware sherds include both engraved and red-slipped vessels (see Table 2). The red-slipped vessels were probably otherwise plain on both the rim and the body, but we cannot be certain of this because there are no red-slipped rims in the assemblage. One of the red-slipped vessel sherds (Unit 2, 10-20 cm bs) may be from a shell-tempered bowl. The engraved vessels were usually decorated on the rim of bowls and carinated bowls and on the body of bottles. The body to rim ratio is a low 2.6:1.

There are a number of different decorative elements in the engraved fine wares (Figure 9a-f), although many of the sherds simply have a single straight or curvilinear line with an uncertain orientation. One of the more distinctive is a bottle sherd (Unit 3, 10-20 $\mathrm{cm}$ bs) with a cross-hatched engraved panel (Figure 9a); the engraved lines are filled with a red pigment. Another bottle sherd (Unit 3,30-40 cm bs) has part of a circular element (Figure 9e).



Figure 9. Engraved rim and body sherds from the South Lilly \#4 site. 
Among the sherds from carinated bowls, several have parts of an engraved scroll element (see Figure 9d, ST 5, 20-40 cm bs), and another has engraved and excised lines from a Ripley Engraved vessel (see Figure 9f, Unit 2, 30-40 cm bs). One has a set of broad curvilinear lines (see Figure 9c, Unit 3, 10-20 cm bs), and there is a red pigment smeared in the engraved lines. One small rim, with horizontal and diagonal engraved lines below the rim, also has a small suspension hole on the rim (see Figure 9b, Unit 3, 10-20 $\mathrm{cm}$ bs). The carinated bowls have direct rims, with rounded and exterior folded lips.

As we previously mentioned, the utility wares from the South Lilly \#4 site are dominated by brushing, usually applied to the body of cooking jars, with lesser amounts of brushed-incised, incised, punctated, punctated-incised, and appliqued sherds (see Table 2).

All three of the brushed rims have horizontal brushing marks on them (Figure 10b and Figure 11c). The rims are direct, with exterior folded lips. The body sherds have both parallel ( $\mathrm{n}=68$, Figure $10 \mathrm{e}-\mathrm{f})$, overlapping $(\mathrm{n}=5$, Unit $2,20-30 \mathrm{~cm}$, Unit $3,10-20 \mathrm{~cm}$, Unit $3,20-30 \mathrm{~cm}$, Unit $3,40-50 \mathrm{~cm}$, and Unit $1 / 2$ profile, Figure $10 \mathrm{~d})$ and opposed $(\mathrm{n}=1$, Unit $1,0-10 \mathrm{~cm}$ bs) brushing marks on them. These brushed sherds may be from Bullard Brushed or Maydelle Incised vessels, or other utility wares with brushed vessel bodies.

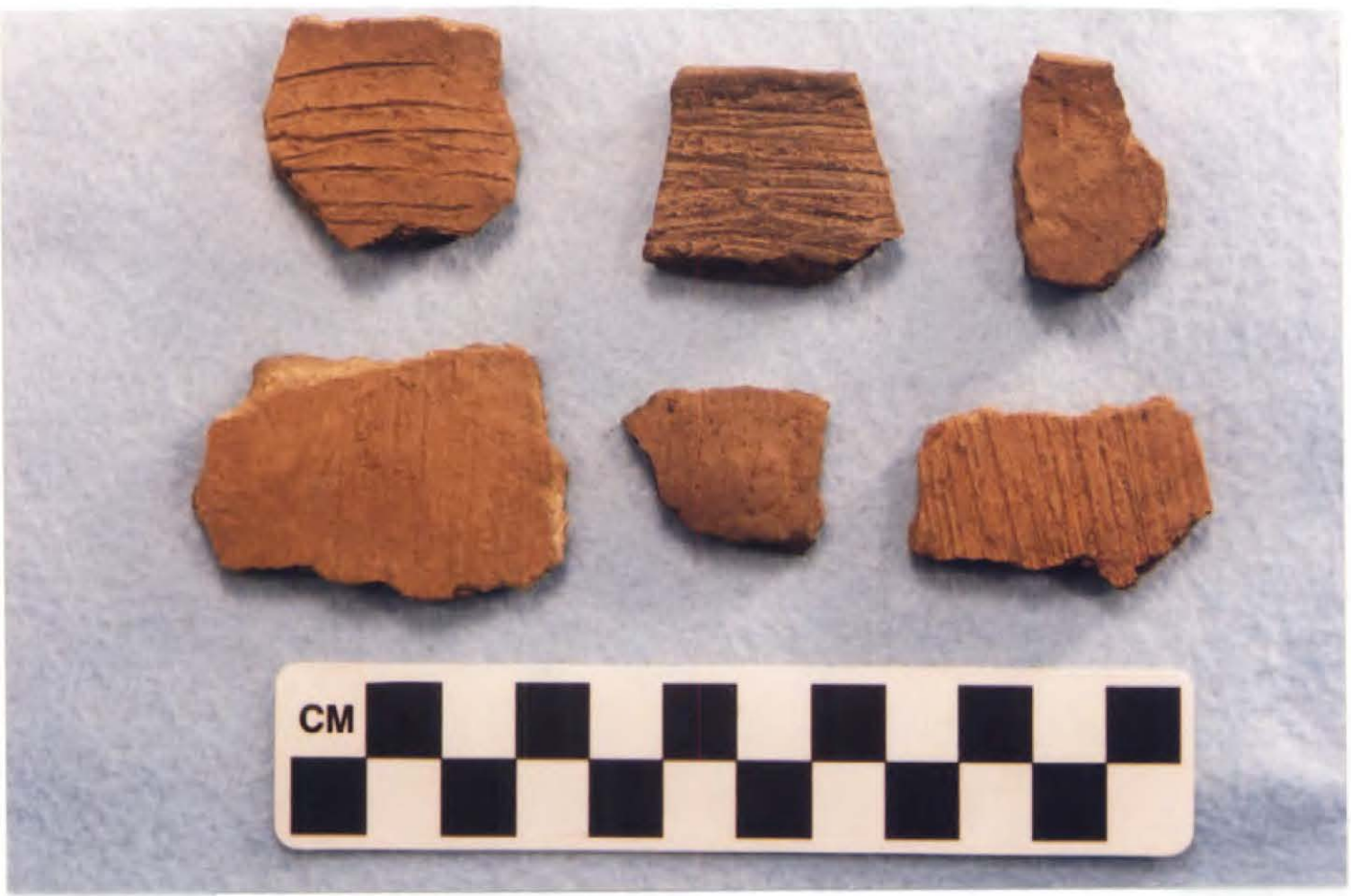

Figure 10. Incised, brushed, and punctated utility ware sherds.

The brushed-incised sherds all have parallel brushed and incised lines, and they are all apparently from the body of cooking jars. The brushed and incised lines probably are oriented vertically on vessel bodies.

Among the incised sherds, one rim (ST 2, 0-20 cm) has a single horizontal incised below the lip, while another has sets of opposed incised lines (Unit 3, 0-10 cm bs), and is perhaps a late variety of Dunkin Incised. Body sherds include the following elements: parallel incised, closely-spaced $(n=9)$; parallel incised, widely-spaced $(n=8)$; parallel incised, closely and widely-spaced ( $\mathrm{n}=2$, see Figure 10a); diagonal and horizontal incised $(n=1)$; diagonal and parallel incised $(n=1)$; cross-hatched $(n=1)$; paneled incised $(n=2$, see 
Figure 11a); and single straight incised line $(\mathrm{n}=2)$. The paneled incised sherds (Unit 1 and Unit 2, 0-10 cm bs) have opposed sets of diagonal incised lines filled with short incised lines filling the diagonal incised panels.

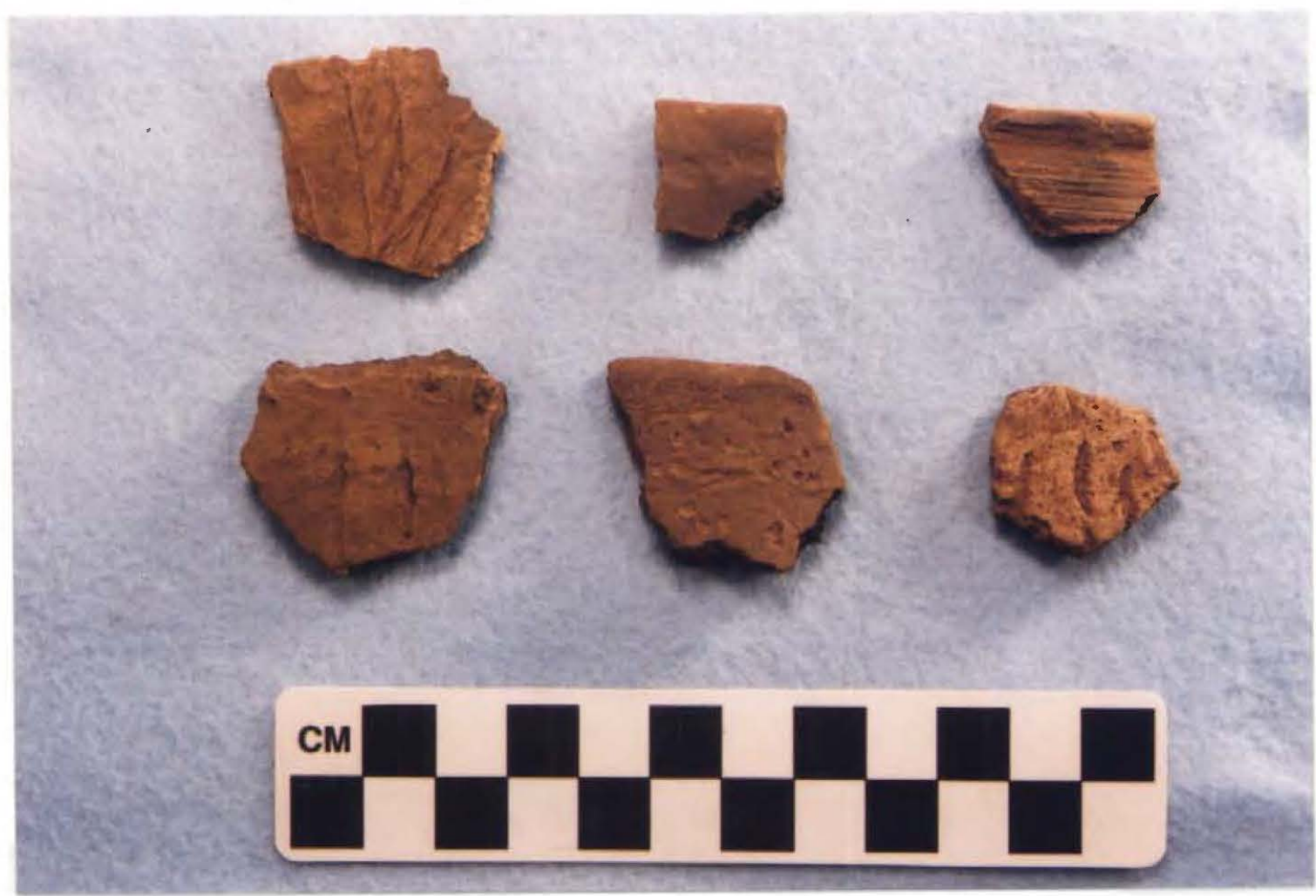

Figure 11. Incised, incised-punctated, brushed, punctated, and plain rim and body sherds.

One of the punctated rims has a row of tool punctations below the lip (see Figure $10 \mathrm{c}$, Unit 3, 20-30 cm), and the other has rows of cane punctations encircling the vessel rim (see Figure 11e, Unit $2,10-20 \mathrm{~cm}$. The body sherds also have rows of punctations, either fingernail-punctated $(\mathrm{n}=2)$ (see Figure $11 \mathrm{~g}$, Unit 2, 20-30 cm bs and Unit 3,0-10 cm bs) or tool punctated. The one punctated-incised sherd has a set of vertically incised lines on the vessel body, with a row of tool punctates at the rim-body juncture (see Figure 11d, Unit 1, 20-30 cm bs). Both appliqued sherds (Unit $1,20-30 \mathrm{~cm}$ bs and Unit 2, 20-30 cm bs) have narrow appliqued ridges on vessel bodies; these probably served as panel dividers on large jars.

The sherds are tempered primarily with grog, with small amounts of bone or hematite added to the paste in both the fine wares and utility wares (Table 3). About 9.3$14.6 \%$ of the sherds had bone temper-either by itself or in combination with grog-and 4.7-14.3\% of the sherds had a hematite temper. The fine wares had a more heterogeneous use of tempering inclusions, including one sherd with a possible shell temper (although eroded away), while grog temper was much more commonly used in the manufacture of the utility ware vessels. 
Table 3. Tempers used in the $41 \mathrm{UR279}$ ceramics.

\begin{tabular}{lll}
\hline Temper & Utility Ware & Fine Ware \\
\hline Grog & $81.4 \%$ & $57.1 \%$ \\
Grog-organics & $3.9 \%$ & $10.7 \%$ \\
Grog-bone & $8.5 \%$ & $10.7 \%$ \\
Grog-hematite & $4.7 \%$ & $3.6 \%$ \\
Grog-hematite-organics & - & $10.7 \%$ \\
Grog-grit & $0.8 \%$ & - \\
Bone & $0.8 \%$ & $3.6 \%$ \\
Shell (?) & - & $3.6 \%$ \\
\hline \multicolumn{1}{c}{ Totals } & & \\
\hline
\end{tabular}

Between 7-7.1\% of the utility ware and fine ware sherds are from vessels that were made using a naturally sandy clay, and they have a noticeable sandy paste; most of these were also tempered solely with grog. The remainder of the sherds have a clay paste, and the clays were probably obtained from sources near to the site.

The utility ware and fine ware vessels were not fired in the same ways (Table 4), although most of the sherds are from vessels fired in a low oxygen or reducing environment; that is, the vessels were smothered while in the fire, and were regularly left smothered while the fire cooled. More than $89 \%$ of the fine wares were fired in a reducing environment, apparently to produce hard and durable vessels, compared to only $62 \%$ of the utility wares. Most of these vessels were then pulled from the fire after they had been fired, and allowed to cool in the open air, leaving a thin and earth-colored oxidized zone on either one or both vessel surfaces. The other vessels fired in a reducing environment had gray to dark gray colors on interior and exterior surfaces.

Table 4. Firing conditions in the $41 \mathrm{UR} 279$ ceramics.

\begin{tabular}{lll}
\hline Firing Conditions & Utility Ware & Fine Ware \\
\hline $\begin{array}{l}\text { Oxidizing environment } \\
\text { Incompletely oxidized }\end{array}$ & $18.5 \%$ & $7.1 \%$ \\
$\begin{array}{l}\text { Reducing environment } \\
\begin{array}{l}\text { Reducing, but cooled in } \\
\text { the open air }\end{array}\end{array}$ & $18.6 \%$ & $3.6 \%$ \\
Refired & $40.3 \%$ & $32.1 \%$ \\
& $0.8 \%$ & $57.1 \%$ \\
\multicolumn{1}{c}{ Totals } & 129 & - \\
\hline
\end{tabular}

Only $10.7 \%$ of the fine wares were fired in an open air, or else incompletely oxidized during firing, but more than $37 \%$ of the utility ware sherds were fired in these ways. We suspect this difference is related to the length of time the utility ware vessels 
were fired, and they were probably not particularly hard or durable, but serviceable enough to stand up to the repeated exposure to heat during cooking use. The utility ware vessels surely had a shorter use-life than the fine ware vessels at the South Lilly \#4 site, and this is reflected in the differences between the two classes of vessels in firing conditions.

Daub ( $n=138)$ and/or burned clay $(n=10)$ were also common in the archaeological deposits, particularly in the hand-excavated units. Their total weight is 107.9 grams. Their occurrence here indicates that there was at least one clay and thatch-covered house structure built on the site; the burned clay may be from the lining of hearths or dispersed pieces of earth that had been exposed to a fire.

\section{Lithic Artifacts}

Chipped stone tools are not particularly abundant at the South Lilly \#4 site. The six tools include an Ellis point found on the surface, made from brown novaculite (Figure 12a); the stem of a contracting stem Gary dart point (Figure 12b, Unit 1, 20-30 cm bs); a petrified wood gouge (Figure 12c, Unit 3, 30-40 cm bs); a dart point mid-section made of quartzite (Unit 2, 30-40 cm bs), a quartzite bifacial tool fragment (Unit 3, 10-20 cm bs); and an expedient flake tool made from a heat-treated quartzite (Unit $1,0-10 \mathrm{~cm}$ bs). Only the latter two chipped stone tools may be associated with the prehistoric Caddo occupation, while the others are the manifestation of site use during the lengthy Woodland period (ca. 500 B.C.-A.D. 800).

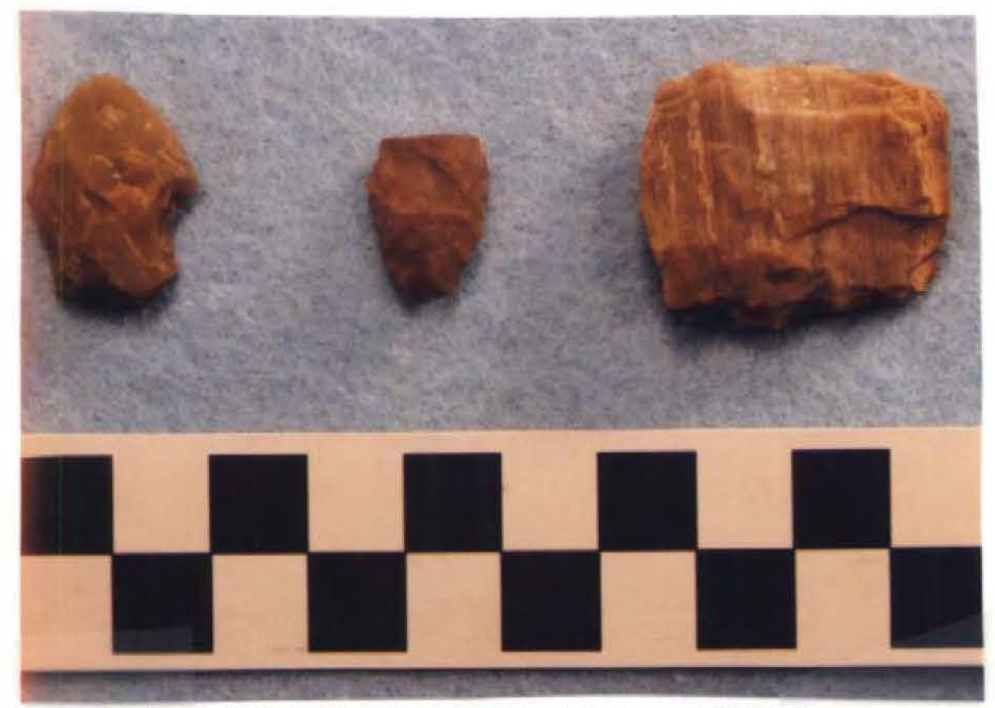

Figure 12. Chipped lithic tools from the South Lilly \#4 site (41UR279).

There were 330 pieces of lithic debris from the archaeological investigations, including one piece collected from the surface (Table 5). Most of these $(n=281$ or $85 \%)$ were pieces of local quartzite, followed by petrified wood $(n=8,2.4 \%)$, and local earthcolored cherts $(n=15,4.5 \%)$. Non-local raw materials represented in the lithic debris includes novaculite $(n=23,7 \%)$ and gray and dark brown cherts $(n=3,0.9 \%)$ from nonlocal sources. All told, almost $8 \%$ of the lithic debris is from non-local lithic raw material sources, most likely from the Ouachita Mountains and Red River gravels, well to the north of the site. 
Table 5. Lithic debris from 41 UR279.

\begin{tabular}{|c|c|c|c|c|c|c|}
\hline Provenience & Quartzite & $\begin{array}{l}\text { Local } \\
\text { chert }\end{array}$ & $\begin{array}{l}\text { Petrified } \\
\text { wood }\end{array}$ & Novaculite & $\begin{array}{l}\text { non-local } \\
\text { Chert }\end{array}$ & $\mathbf{N}$ \\
\hline Surface & - & - & 1 & - & - & 1 \\
\hline $\begin{array}{l}\text { ST 1 } \\
\text { ST } 2 \\
\text { ST } 3 \\
\text { ST } 4 \\
\text { ST } 5 \\
\text { ST } 6 \\
\text { ST } 7\end{array}$ & $\begin{array}{l}4 \\
5 \\
4 \\
10 \\
9 \\
5 \\
14\end{array}$ & $\begin{array}{l}1 \\
- \\
- \\
- \\
2 \\
- \\
1\end{array}$ & $\begin{array}{l}1 \\
- \\
1 \\
- \\
- \\
- \\
-\end{array}$ & $\begin{array}{l}- \\
1 \\
1 \\
- \\
- \\
- \\
-\end{array}$ & $\begin{array}{l}- \\
- \\
- \\
- \\
- \\
- \\
-\end{array}$ & $\begin{array}{l}6 \\
6 \\
6 \\
10 \\
11 \\
5 \\
15\end{array}$ \\
\hline Sub-total & 51 & 4 & 2 & 2 & 0 & 59 \\
\hline $\begin{array}{l}\text { U1, 0-10 } \\
\text { U1, 10-20 } \\
\text { U1, 20-30 } \\
\text { U1, 20-30FS } \\
\text { U1, 30-40 } \\
\text { U1, 30-40FS }\end{array}$ & $\begin{array}{l}15 \\
22 \\
9 \\
13 \\
21 \\
13\end{array}$ & $\begin{array}{l}3 \\
- \\
- \\
- \\
- \\
1\end{array}$ & $\begin{array}{l}- \\
- \\
1 \\
- \\
- \\
-\end{array}$ & $\begin{array}{l}- \\
- \\
1 \\
2 \\
2 \\
3\end{array}$ & $\begin{array}{l}- \\
1 \\
- \\
- \\
-\end{array}$ & $\begin{array}{l}18 \\
23 \\
11 \\
15 \\
23 \\
17\end{array}$ \\
\hline Sub-total & 93 & 4 & 1 & 8 & 1 & 107 \\
\hline $\begin{array}{l}\text { U2, } 0-10 \\
\text { U2, } 10-20 \\
\text { U2, 20-30 } \\
\text { U2, 20-30FS } \\
\text { U2, 30-40 } \\
\text { U2, 30-40FS }\end{array}$ & $\begin{array}{l}10 \\
12 \\
19 \\
13 \\
14 \\
21\end{array}$ & $\begin{array}{l}- \\
- \\
- \\
- \\
- \\
-\end{array}$ & $\begin{array}{l}- \\
- \\
2 \\
- \\
- \\
-\end{array}$ & $\begin{array}{l}1 \\
2 \\
- \\
3 \\
- \\
4\end{array}$ & $\begin{array}{l}- \\
- \\
- \\
- \\
- \\
-\end{array}$ & $\begin{array}{l}11 \\
14 \\
21 \\
16 \\
14 \\
25\end{array}$ \\
\hline Sub-total & 89 & 0 & 2 & 10 & 0 & 101 \\
\hline $\begin{array}{l}\mathrm{U} 3,0-10 \\
\mathrm{U} 3,10-20 \\
\mathrm{U} 3,20-30 \\
\mathrm{U} 3,30-40 \\
\mathrm{U} 3,40-50\end{array}$ & $\begin{array}{l}8 \\
15 \\
10 \\
11 \\
4\end{array}$ & $\begin{array}{l}- \\
2 \\
- \\
4 \\
1\end{array}$ & $\begin{array}{l}- \\
2 \\
- \\
- \\
-\end{array}$ & $\begin{array}{l}1 \\
1 \\
- \\
1 \\
-\end{array}$ & $\begin{array}{l}- \\
- \\
- \\
1 \\
1\end{array}$ & $\begin{array}{l}9 \\
20 \\
10 \\
17 \\
6\end{array}$ \\
\hline Sub-total & 48 & 7 & 2 & 3 & 2 & 62 \\
\hline Totals & 281 & 15 & 8 & 23 & 3 & 330 \\
\hline
\end{tabular}

About $30 \%$ of the local quartzite and chert lithic debris are cortical; none of the petrified wood pieces have cortex, as is the case for the novaculite; for the latter, we suspect that completed novaculite tools were only resharpened on the site, and had been manufactured elsewhere. This conclusion is further supported by the relatively high amounts of small non-cortical lithic debris pieces in the Unit 1 and Unit 2 fine-screen samples (see Table 5). The relatively high percentage of cortical flakes in the local raw 
materials suggests that small cobbles of raw material were being reduced and knapped on the site, mainly to produce flakes large enough to be suitable for tools.

We recovered 15 pieces of quartzite and ferruginous sandstone fire-cracked rock, weighing in total $0.86 \mathrm{~kg}$. Most of the pieces came from Unit $2(n=5)$ and Unit $3(n=6)$ between $20-50 \mathrm{~cm}$ bs. Some amount of indirect cooking with heated rocks must have taken place at the South Lilly \#4 site, probably during the Woodland period occupation of the site.

\section{Charred Plant Remains}

Charred plant remains were present throughout the archaeological deposits, especially in the fine-screen samples from midden deposits in Unit 1 and Unit 2. A total of 874 pieces (weighing $32.7 \mathrm{~g}$ ) were recovered, principally charred hickory nutshells, obviously the residues of processing hickory nuts for their meat and oil.

By weight, almost $58 \%$ of the charred plant remains were collected in the $1 / 4$-inch screen samples, with the remainder coming in the fine-screen (1/32-inch) samples from the aforementioned two samples. More than $75 \%$ of the charred plant remains by count, however, came from the fine-screen samples $(n=663)$, indicating the generally small size of the processed and discarded plant remains at the site. Only 211 pieces were collected from the 1/4-inch screening of sediments from the shovel tests and hand-excavated units. 


\section{FAUNAL ANALYSIS, LeeAnna Schniebs}

Archaeological investigations at the South Lilly \#4 site (41UR279) on South Lilly Creek in Upshur County, Texas, yielded 285 faunal specimens. Total weight of the sample is 57.83 grams. Faunal material was recovered from four shovel tests and three handexcavated units in midden deposits, including fine screen samples taken in Units 1 and 2. Depths range from 0 to 70 centimeters below surface $(\mathrm{cm} \mathrm{bs})$. The following sections of the faunal analysis discuss the methods employed in the faunal analysis, results of taxonomic identification and quantification, and distribution of these remains.

All prehistoric vertebrate remains were inventoried and weighed. Excel for Windows was used to manipulate the generated faunal data. An Ohaus digital scale, Model CT600-S, was used to record bone weight. All fragments recovered were analyzed by the author, using comparative collections on loan from or housed at the Institute of Applied Sciences, Zooarchaeology Lab, University of North Texas, Denton, Texas. Occasional supplements were required, using conventional osteological keys such as Olsen (1964), Gilbert (1980), and Schmid (1972). Identifications were made to the most specific category possible depending on the condition of the bone and available comparative materials. Only positive identifications resulted in the assignment of elements to genus or species.

Standard zooarchaeological methods have been used. The animal bones were inventoried and bagged by personnel from Archeological and Environmental Consultants, LLC (Pittsburg, Texas, office), then submitted for identification and quantification. Both unidentifiable and identifiable pieces were analyzed in similar fashion. That is, the same attributes were recorded on each identifiable piece: taxon, element and portion of that element, anatomical location of the element, condition of the bone and any notes on age, taphonomy, burning or breakage patterns, and presence of modification if applicable. Provenience information was also recorded.

Quantification of the assemblage is summarized as number of identified specimens per taxon (NISP) and as minimum number of individuals (MNI) for identified elements. MNI estimates were calculated according to the most frequently occurring element, based on symmetry and element portion (Munzel 1986). In the mammalian class, teeth were used whenever possible. In some cases, complete long bones and proximal or distal ends were considered. In other cases, the presence of a single element constituted an MNI of one.

The faunal data tables provided in this section of the article comprise standard species lists with the number of occurrences for each animal. Those specimens regarded as unidentifiable (those coded to only class) have been consolidated into a few general categories. Elements of non-diagnostic skeletal value (i.e., unidentifiable fragments, ribs, vertebrae, and long bone shafts, see Olsen [1964]), are coded in an indeterminate category by class and size range. For example, specimens counted as "unidentifiable mammal" are from indeterminate-size mammals; "small mammal" is rabbit or squirrel-size; "medium mammal" is at least dog-size; and "large mammal" refers to a deer-size mammal. "Indeterminate vertebrate" includes the bones of unidentifiable class. Recording these specimens in a size category enables the most precise level of observation as the specimen allows. In small samples, taking note of weight and the size categories of non-diagnostic elements broadens the function of the bone assemblage. However, percentages referred to in this article are calculated by number of bones (NISP) rather than weight. A complete inventory of the faunal collection from the South Lilly \#4 site (41UR279) can be found in Appendix 3 accompanying this article. 


\section{Results}

Reptilia and mammalia (carnivora and artiodactyla) are the only taxonomic classes identified. The sample is comprised of 42 indeterminate vertebrate bone fragments, four small pieces of unidentifiable turtle shell, seven indeterminate mammal bones, 121 . unidentifiable small mammal bones, 25 medium mammal bones, 72 unidentifiable large mammal bones, one raccoon tooth, nine medium artiodactyl bones, and four deer tooth fragments. The following section describes the identifiable vertebrate taxa recovered from the South Lilly \#4 site. Number of identified specimens (NISP) and minimum number of individuals (MNI) for each taxon are summarized in Table 6, as are weights for each taxon and percentages of the assemblage. Composition of anatomical elements can be found in Table 7.

\section{Table 6. Taxonomic composition of the $41 \mathrm{UR279}$ faunal sample.}

\begin{tabular}{|l|l|r|r|r|r|}
\hline Scientific Name & Common Name & NISP & MNI & \% of Sample Wt./g \\
\hline Vertebrata (indeterminate) & unidentifiable & 42 & & 15 & 0.71 \\
Testudinata & turtle & 4 & 1 & 1 & 0.11 \\
Mammalia (indeterminate) & mammal & 7 & & 2 & 0.3 \\
\hline Mammalia (small) & sm. mammal & 121 & 1 & 43 & 1.96 \\
\hline Mammalia (medium) & med. mammal & 25 & & 9 & 2.8 \\
Mammalia (large) & Ig. mammal & 72 & & 25 & 19.8 \\
\hline Procyon lotor & raccoon & 1 & 1 & 1 & 0.1 \\
Artiodactyla (medium) & deer-size artiodactyl & 9 & & 3 & 31.4 \\
\hline Odocoileus sp. & deer & 4 & 1 & 1 & 0.65 \\
& TOTAL & 285 & & 100 & 57.83 \\
\hline
\end{tabular}

\section{Assemblage Composition}

Class Reptilia

Order Testudinata (family indeterminate)

Four small shell fragments from unidentifiable turtle were recovered from two levels in two units. Fine screen samples taken in Unit 1 ( $20-30$ and $30-40 \mathrm{~cm}$ bs) yielded three specimens, and one piece came from Unit $2(20-30 \mathrm{~cm}$ bs $)$. The fragments are burned. Turtle remains are common in prehistoric faunal assemblages, and often apparently supplemented the prehistoric Caddo diet. 
Table 7. Composition of faunal elements from $41 \mathrm{UR279.}$

\begin{tabular}{|c|c|c|c|c|c|c|c|c|}
\hline \multirow[t]{2}{*}{ Scientific Name } & \multirow[t]{2}{*}{ Common Name } & \multicolumn{2}{|c|}{ Element } & \multirow[b]{2}{*}{ cranial } & \multirow[b]{2}{*}{ axial } & \multirow[b]{2}{*}{ long bone } & \multirow[b]{2}{*}{$\mathrm{pod} / \mathrm{ph} \mathrm{x}$} & \multirow[b]{2}{*}{ other } \\
\hline & & unid. 1 & teeth & & & & & \\
\hline Vertebrata (indeterminate) & unidentifiable & 41. & & & & 1 & & \\
\hline Testudinata & turtle & & & & & & & 4 \\
\hline Mammalia (indeterminate) & mammal & 7 & & & & & & \\
\hline Mammalia (small) & sm. mammal & 117 & & & & 4 & & \\
\hline Mammalia (medium) & med. mammal & 20 & 2 & 1 & & 2 & & \\
\hline Mammalia (large) & Ig. mammal & 44 & & 1 & 1 & 26 & & \\
\hline Procyon lotor & raccoon & & 1 & & & & & \\
\hline Artiodactyla (medium) & deer-size artiodactyl & & & 1 & & 6 & 2 & \\
\hline \multirow[t]{2}{*}{ Odocoileus sp. } & deer & & 4 & & & & & \\
\hline & TOTAL & 229 & 7 & 3 & 1 & 39 & 2 & 4 \\
\hline \multicolumn{9}{|l|}{ NOTE: } \\
\hline \multicolumn{9}{|c|}{ "Teeth" inc. six enamel frags and one complete tooth. } \\
\hline \multirow{2}{*}{\multicolumn{9}{|c|}{$\begin{array}{l}\text { "Cranial" inc. one skull frag, one mandible frag, and one tooth socket frag. } \\
\text { "Axial" inc. one vertebral epiphysis frag. }\end{array}$}} \\
\hline & & & & & & & & \\
\hline \multicolumn{9}{|l|}{ "Long bone" inc. shaft frags. } \\
\hline \multicolumn{9}{|c|}{ "Pod/phx" inc. one calcaneus frag and one phalanx frag. } \\
\hline "Other" inc. turtle shell frags & & & & & & & & \\
\hline
\end{tabular}

Class Mammalia

Order Carnivora, Family Procyonidae

Raccoon (Procyon lotor) is represented by a single tooth. It was recovered from a fine screen sample taken in Unit $1(30-40 \mathrm{~cm}$ bs). The range of the raccoon includes the northeastern Texas area, occurring also throughout most of the country. The preferred habitats are streams and lake borders near wooded areas or rock cliffs (Burt and Grossenheider 1980). The raccoon may have been hunted for its pelt as well as the edible meat.

\section{Order Artiodactyla, Family Cervidae}

Deer (Odocoileus sp.) is represented by four tooth fragments. They were recovered from Shovel Test $2(20-40 \mathrm{~cm}$ bs), Shovel Test $4(20-40 \mathrm{~cm}$ bs), Unit $1(20-30 \mathrm{~cm}$ bs), and a fine screen sample taken in Unit $1(30-40 \mathrm{~cm}$ bs). One specimen is charred. Whitetail Deer (Odocoileus virginianus) is the only species in Family Cervidae that currently occupies the general region, and is found in forests, swamps, and open brushy areas nearby (Burt and Grossenheider 1980). Deer is the most common large game animal preferred by the Caddo, and also one of their main subsistence animals. The Caddos were adept imitators of deer, and a hunter disguised with the antlers and hide of a deer was able to approach his quarry closely, and even to attract it to himself (Newcomb 1993).

Nine medium artiodactyl bones were recovered from Shovel Test $2(70 \mathrm{~cm}$ bs) and Units 1, 2, and $3(0-50 \mathrm{~cm}$ bs). This includes one toe bone fragment found in Feature 1 in 
Unit $1(54 \mathrm{~cm}$ bs). Six medium artiodactyl bones are burned. These specimens are probably the remains of deer. Although pronghorn is also categorized as a medium-sized artiodactyl, a specific identification cannot be made based on post-cranial bone fragments. But since no pronghorn tooth fragments were recovered, it is probably safe to assume that no pronghorn were present at the site. Both animals are similar in size, but pronghorn antelope are found in open prairies and sagebrush plains well outside of most of the northeastern Texas region (Burt and Grossenheider 1980). Pronghorn currently reside in the western half of Texas from the Panhandle to the lower Rio Grande valley (Davis 1978). However, one pronghorn element was recovered from the Hurricane Hill site (41HP106), a prehistoric Early and Middle Caddoan habitation site at Cooper Reservoir in nearby Hopkins County (Yates 1999). Henderson (1978) reported pronghorn remains at the Arnold and Luna sites at Cooper Lake; both of these sites have Woodland and prehistoric Caddoan components.

Medium artiodactyl (deer) is probably also represented in the unidentifiable large mammal eategory $(n=72)$. Large mammal bone fragments were recovered from the four shovel tests and the three units, and depths range from 0 to $46 \mathrm{~cm}$ bs. A total of 49 large mammal specimens are burned.

The unidentifiable small mammal bones $(n=121)$ may represent rabbit or squirrel. Most of the sinall mammal bones came from fine screen samples taken in Units 1 and 2 $(n=120)$. These are common animals found in Caddoan faunal assemblages. They are easily procured by hunters, and are often dietary supplements. At least some of the 25 unidentifiable medium-sized mammal bones may be the remains of the previously mentioned raccoon.

\section{Assemblage Condition}

In general, the faunal material from the site is highly fragmented. This probably explains the low amount of identified faunal remains. Taphonomic patterns were absent on 238 fragments (Table 8). Surface observations on the remaining specimens include abrasion and exfoliation. Eighty-eight percent of the site sample is burned $(n=252)$, probably a result of trash disposal. Summary of burned specimens can be found in Table 9 , and the distribution of these burned remains can be found in Table 10.

\section{Table 8. Summary of taphonomic patterns on 41 UR279 faunal specimens.}

\begin{tabular}{|c|c|c|c|c|c|}
\hline Scientific Name & Common Name & $\begin{array}{l}\text { Taphon } \\
\text { absent }\end{array}$ & omy Type & exfoliated & abrade+exfol \\
\hline Vertebrata (indeterminate) & unidentifiable & 41 & & 1 & \\
\hline Testudinata & turtle & 4 & & & \\
\hline Mammalia (indeterminate) & mammal & 1 & 6 & & \\
\hline Mammalia (small) & sm. mammal & 120 & & 1 . & \\
\hline Mammalia (medium) & med. mammal & 23 & & 2 & \\
\hline Mammalia (large) & lg. mammal & 38 & 17 & 15 & 2 \\
\hline Procyon lotor & raccoon & 1 & & & \\
\hline Artiodactyla (medium) & deer-size artiodactyl & 6 & & 2 & 1 \\
\hline Odocoileus sp. & deer & 4 & & & \\
\hline & TOTAL. & 238 & 23 & 21 & 3 \\
\hline
\end{tabular}


Table 9. Summary of burning patterns on $41 \mathrm{UR} 279$ faunal specimens.

\begin{tabular}{|c|c|c|c|c|c|}
\hline Scientific Name & Common Name & $\begin{array}{l}\text { Degree of Burning } \\
\text { not burned charred }\end{array}$ & & white & black \\
\hline Vertebrata (indeterminate) & unidentifiable & 1 & & 41 & \\
\hline Testudinata & turtle & & & 4 & \\
\hline Mammalia (indeterminate) & mammal & & & 7 & \\
\hline Mammalia (small) & sm. mammal & $2^{+}$ & & 118 & 1 \\
\hline Mammalia (medium) & med mammal & & & 19 & 6 \\
\hline Mammalia (large) & ig. mammal & 23 & 1 & 37 & 11 \\
\hline Procyon lotor & raccoon & 1 & & & \\
\hline Artiodactyla (medium) & deer-size artiodactyl & 3 & 2 & 1 & 3 \\
\hline Odocoileus sp. & deer & 3 & 1 & & \\
\hline & TOTAL & 33 & 4 & 227 & 21 \\
\hline
\end{tabular}

In addition to weathering, spiral fracturing was recorded during the faunal analysis. Spiral fractures are the result of impact, such as striking the bone with a hammerstone or breaking on an anvil. It is a common, expedient technique used in tool manufacturing, bone processing, and refuse disposal. Usually associated with large mammal long bones, spiral fracturing can also occur during trampling, carnivore gnawing, or any other severe impacts not necessarily associated with human activity. Five medium-sized artiodactyl and 12 large mammal bones are recorded as spirally fractured (Table 11). The remainder of the large mammal sample is angularly fractured, suggesting that the bone was broken when it was dry, rather than while green and fresh. Perhaps after processing, it was broken into smaller pieces for disposal.

Scavenging activities are relatively minimal. Rodent gnawing was observed on three specimens, while carnivore gnawing was noted on only one fragment (see Table 11).

\section{Distribution}

The following section discusses the distribution of the South Lilly \#4 site faunal collection across the site. This information can be found in Tables 12 and 13. Fine screen recovery is summarized in Table 14.

\section{Shovel Tests}

Four shovel tests yielded 13 faunal specimens. A burned large mammal long bone fragment was recovered from Shovel Test $1(20-30 \mathrm{~cm}$ bs). Four specimens came from Shovel Test 2: a deer tooth fragment and a burned large mammal long bone fragment came from the second level $(20-40 \mathrm{~cm}$ bs), and two medium artiodactyl metapodial fragments were found at $70 \mathrm{~cm}$ bs. Three levels in Shovel Test 4 contained five specimens. Two large mammal long bone fragments were in the first level $(0-20 \mathrm{~cm} \mathrm{bs})$, a deer tooth fragment and one large mammal bone came from the second level $(20-40 \mathrm{~cm} \mathrm{bs})$, and one small mammal long bone fragment was found in the third level $(40-60 \mathrm{~cm} \mathrm{bs})$. Four specimens from Shovel Test 4 are burned. Two levels in Shovel Test 5 yielded three burned 
Table 10. Distribution of 41 UR279 burned faunal specimens by unit and level.

\begin{tabular}{|c|c|c|c|c|c|c|c|}
\hline \multirow{2}{*}{$\begin{array}{l}\text { Unit } \\
\text { Shove }\end{array}$} & \multirow{2}{*}{$\begin{array}{l}\text { Scientific Name } \\
\text { Test } 1(B=1)\end{array}$} & \multirow[t]{3}{*}{ Common Name } & \multicolumn{2}{|c|}{ Depth (cm bs) } & & & \\
\hline & & & 20 to 40 & & & & \\
\hline & Mammalia (large) & & 1 & & & & \\
\hline \multicolumn{3}{|c|}{ Shovel Test $2(B=1)$} & 20 to 40 & & & & \\
\hline & Mammalia (large) & Ig. mammal & 1 & i & & & \\
\hline \multicolumn{2}{|c|}{ Shovel Test $4(B=4)$} & & Oto20 & 20 to 40 & 40 to60 & & \\
\hline & Mammalia (small) & sm. mammal & & & 1 & & \\
\hline & Mammalia (large) & Ig. mammal & 2 & 1 & & & \\
\hline \multicolumn{2}{|c|}{ Shovel Test $5(B=3)$} & & Oto20 & 20 to 40 & & & \\
\hline & Mammalia (indeterminate) & mammal & 1 & & & & \\
\hline & Mammalia (large) & Ig. mammal & & 2 & & & \\
\hline \multicolumn{2}{|c|}{ Unit $1(B=106)$} & & Oto10 & 10 to 20 & 20 to 30 & 30 to 40 & $\mathrm{~F}-1$ (54cmbs) \\
\hline & Vertebrata (indeterminate) & unidentifiable & & & 13 & 14 & \\
\hline & Testudinata & turtle & & & 2 & 1 & \\
\hline & Mammalia (indeterminate) & mammal & & 6 & & & \\
\hline & Mammalia (small) & sm. mammal & & & 19 & 18 & \\
\hline & Mammalia (medium) & med. mammal & & & 10 & 3 & \\
\hline & Mammalia (large) & Ig. mammal & 2 & 3 & 7 & 4 & \\
\hline & Artiodactyla (medium) & deer-size artiodactyl & & 1 & 1 & & 1 \\
\hline & Odocoileus sp. & deer & & & 1 & & \\
\hline & & TOTAL & 2 & 10 & 53 & 40 & 1 \\
\hline \multicolumn{2}{|c|}{ Unit $2(B=125)$} & & 10 to 20 & 20 to 30 & 30 to 40 & & \\
\hline & Vertebrata (indeterminate) & unidentifiable & & 5 & 9 & & \\
\hline & Testudinata & turtle & & 1 & & & \\
\hline & Mammalia (small) & sm. mammal & & 39 & 42 & & \\
\hline & Mammalia (medium) & med. mammal & & 3 & 8 & & \\
\hline & Mammalia (large) & Ig. mammal & 4 & 12 & 1 & & \\
\hline & Artiodactyla (medium) & deer-size artiodactyl & & & 1 & & \\
\hline & & TOTAL & 4 & 60 & 61 & & \\
\hline \multicolumn{2}{|c|}{ Unit $3(B=12)$} & & 10 to 20 & 20 to 30 & 30 to 40 & 40 to50 & \\
\hline & Mammalia (medium) & med. mammal & & & 1 & & \\
\hline & Mammalia (large) & Ig. mammal & 5 & 2 & 2 & & \\
\hline & Artiodactyla (medium) & deer-size artiodactyl & & & 1 & 1 & \\
\hline
\end{tabular}




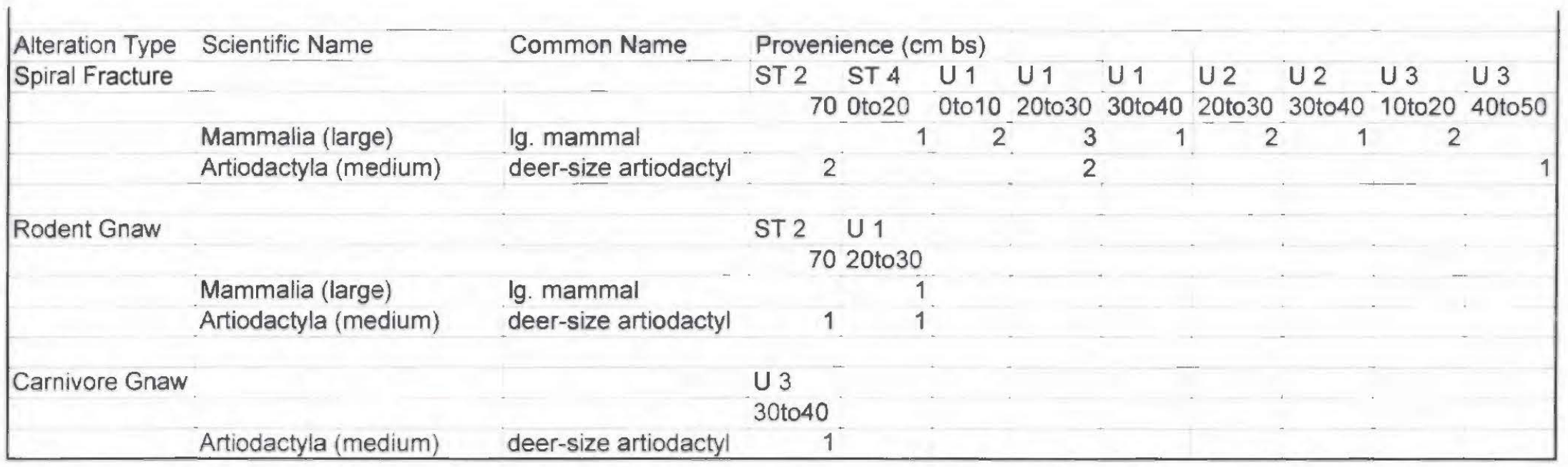




\section{Table 12. General distribution of 41 UR279 faunal collection.}

\begin{tabular}{|c|c|c|c|c|c|c|}
\hline \multirow{2}{*}{$\begin{array}{l}\text { Unit Type } \\
\text { Shovel Tes }\end{array}$} & \multirow{2}{*}{$\begin{array}{l}\text { Scientific Name } \\
\text { sts }\end{array}$} & \multirow{2}{*}{ Common Name } & \multicolumn{2}{|c|}{ Provenience } & \multirow[b]{2}{*}{ ST 4} & \multirow[b]{2}{*}{ ST 5} \\
\hline & & & ST 1 & ST 2 & & \\
\hline & Mammalia (indeterminate) & mammal & & & & 1 \\
\hline & Mammalia (small) & sm. mammal & & & 1 & \\
\hline & Mammalia (large) & Ig. mammal & 1 & 1 & 3 & 2 \\
\hline & Artiodactyla (medium) & deer-size artiodactyl & & 2 & & \\
\hline & Odocoileus sp. & deer & & 1 & 1 & \\
\hline & & TOTAL & 1 & 4 & 5 & 3 \\
\hline \multirow[t]{11}{*}{ Units } & & & U 1 & U 2 & U 3 & \\
\hline & Vertebrata (indeterminate) & unidentifiable & 28 & 14 & & \\
\hline & Testudinata & turtle & 3 & 1 & & \\
\hline & Mammalia (indeterminate) & mammal & 6 & & & \\
\hline & Mammalia (small) & sm. mammal & 37 & 83 & & \\
\hline & Mammalia (medium) & med. mammal & 13 & 11 & 1 & \\
\hline & Mammalia (large) & Ig. mammal & 26 & 23 & 16 & \\
\hline & Procyon lotor & raccoon & 1 & & & \\
\hline & 'Artiodactyla (medium) & deer-size artiodactyl & 4 & 1 & 2 & \\
\hline & Odocoileus sp. & deer & 2 & & & \\
\hline & & TOTAL & 120 & 133 & 19 & \\
\hline
\end{tabular}

specimens. One unidentifiable mammal bone came from $0-20 \mathrm{~cm}$ bs, and two large mammal bones were recovered from $20-40 \mathrm{~cm}$ bs.

\section{Unit 1}

Unit 1 had 120 faunal specimens, comprised of 34 fragments from four levels, 85 pieces from fine screen samples taken in two of these levels, and one medium artiodactyl toe bone fragment from Feature 1. Two large mammal long bone fragments came from the first level $(0-10 \mathrm{~cm} \mathrm{bs})$, and Level $2(10-20 \mathrm{~cm}$ bs) yielded six unidentifiable mammal bones, six large mammal bones, and one medium-sized artiodactyl radius fragment. The third level $(20-30 \mathrm{~cm}$ bs) had the majority of remains $(n=60)$, but most of these specimens came from a fine screen sample $(n=43)$. The collection from Level 3 is comprised of indeterminate vertebrate, turtle, unidentifiable small, medium, and large mammal, medium artiodactyl, and deer. Level $4(30-40 \mathrm{~cm}$ bs) yielded 44 faunal specimens, including 42 fragments from a fine screen sample. Taxonomic recovery is similar to that of Level 3, except for the addition of raccoon and the absence of medium artiodactyl. A total of 106 specimens from Unit 1 are burned.

\section{Unit 2}

Unit 2 yielded a total of 133 faunal specimens, comprised of 25 fragments from four levels and 108 pieces from fine screen samples taken in two of these levels. Only four large mammal bones were found in Level $2(10-20 \mathrm{~cm}$ bs). Sixty-one fragments were recovered from Level $3(20-30 \mathrm{~cm}$ bs), including 49 specimens from a fine screen sample. Level $4(30-40 \mathrm{~cm}$ bs) yielded 66 fragments, including 59 pieces from a fine screen sample. Two large mammal bones were recovered at $46 \mathrm{~cm}$ bs. Taxonomic recovery from Unit 2 is dominated by small mammal remains. The remainder of the unit sample consists of indeterminate vertebrate, turtle, unidentifiable medium, and large mammal, and medium artiodactyl. One hundred and twenty five specimens from Unit 2 are burned. 
Table 13. Specific distribution of 41 UR279 faunal specimens by provenience.

\begin{tabular}{|c|c|c|c|c|c|c|c|}
\hline \multirow{2}{*}{$\begin{array}{l}\text { Unit } \\
\text { Shove }\end{array}$} & \multirow{2}{*}{$\begin{array}{l}\text { Scientific Name } \\
\text { Test } 1\end{array}$} & \multirow[t]{3}{*}{ Common Name } & \multicolumn{2}{|c|}{ Depth (cm bs) } & & & \\
\hline & & & 20 to 40 & & & & \\
\hline & Mammalia (large) & & 1 & & & & \\
\hline \multicolumn{2}{|c|}{ Shovel Test 2} & \multirow{3}{*}{$\begin{array}{l}\text { Ig. mammal } \\
\text { deer-size artiodactyl } \\
\text { deer }\end{array}$} & 20 to40 & 70 & & & \\
\hline & Mammalia (large) & & 1 & & & & \\
\hline & $\begin{array}{l}\text { Artiodactyla (medium) } \\
\text { Odocoileus } s p \text {. }\end{array}$ & & 1 & 2 & & & \\
\hline \multicolumn{2}{|c|}{ Shovel Test 4} & & Oto 20 & 20 to 40 & 40 to60 & & \\
\hline & Mammalia (small) & sm. mammal & & & 1 & & \\
\hline & Mammalia (large) & Ig. mammal & 2 & 1 & & & \\
\hline & Odocoileus sp. & deer & & 1 & & & \\
\hline \multirow{2}{*}{\multicolumn{2}{|c|}{$\begin{array}{l}\text { Shovel Test } 5 \\
\qquad \begin{array}{l}\text { Mammalia (indeterminate) } \\
\text { Mammalia (large) }\end{array}\end{array}$}} & mammal & Oto20 & 20 to 40 & & & \\
\hline & & Ig. mammal & & 2 & & & \\
\hline \multicolumn{2}{|c|}{ Unit $1(\mathrm{~N}=120)$} & & Oto10 & 10 to 20 & 20 to 30 & 30 to 40 & $\mathrm{~F}-1(54 \mathrm{cmbs})$ \\
\hline & Vertebrata (indeterminate) & unidentifiable & & & 13 & 15 & \\
\hline & Testudinata & turtle & & & 2 & 1 & \\
\hline & Mammalia (indeterminate) & mammal & & 6 & & & \\
\hline & Mammalia (small) & sm. mammal & & & 19 & 18 & \\
\hline & Mammalia (medium) & med. mammal & & & 10 & 3 & \\
\hline & Mammalia (large) & lg. mammal & 2 & 6 & 13 & 5 & \\
\hline & Procyon lotor & raccoon & & & & 1 & \\
\hline & Artiodactyla (medium) & deer-size artiodactyl & & 1 & 2 & & 1 \\
\hline & Odocoileus sp. & deer & & & 1 & 1 & \\
\hline & & TOTAL & 2 & 13 & 60 & 44 & 1 \\
\hline \multicolumn{2}{|c|}{ Unit $2(\mathrm{~N}=133)$} & & 10 to 20 & 20 to30 & 30 to 40 & 46 & \\
\hline & Vertebrata (indeterminate) & unidentifiable & & 5 & 9 & & \\
\hline & Testudinata & turtle & & 1 & & & \\
\hline & Mammalia (small) & sm. mammal & & 40 & 43 & & \\
\hline & Mammalia (medium) & med. mammal & & 3 & 8 & & \\
\hline & Mammalia (large) & Ig. mammal & 4 & 12 & 5 & 2 & \\
\hline & Artiodactyla (medium) & deer-size artiodactyl & & & 1 & & \\
\hline & & TOTAL & 4 & 61 & 66 & 2 & \\
\hline \multicolumn{2}{|c|}{ Unit $3(N=19)$} & & 10 to 20 & 20 to30 & 30 to 40 & 40 to 50 & \\
\hline & Mammalia (medium) & med. mammal & & & 1 & & \\
\hline & Mammalia (large) & lg. mammal & 5 & 2 & 9 & & \\
\hline & Artiodactyla (medium) & deer-size artiodactyl & & & 1 & 1 & \\
\hline
\end{tabular}


Table 14. Summary of faunal recovery from 41 UR279 fine screen samples.

\begin{tabular}{|c|c|c|c|c|c|}
\hline Scientific Name & Common Name & $\begin{array}{l}\text { Unit } 1 \\
20 \text { to } 30\end{array}$ & $\begin{array}{l}\text { Unit } 1 \\
30 \text { to40 }\end{array}$ & $\begin{array}{l}\text { Unit 2 } \\
\text { 20to30 }\end{array}$ & $\begin{array}{l}\text { Unit 2 } \\
30 \text { to } 40\end{array}$ \\
\hline Vertebrata (indeterminate) & unidentifiable & 13 & 15 & 5 & 9 \\
\hline Testudinata & turtle & 2 & 1 & & \\
\hline Mammalia (indeterminate) & mammal & & & & \\
\hline Mammalia (small) & sm. mammal & 19 & 18 & 40 & 43 \\
\hline Mammalia (medium) & med. mammal & 8 & 3 & 3 & 6 \\
\hline Mammalia (large) & Ig. mammal & & 3 & 1 & 1 \\
\hline Procyon lotor & raccoon & & 1 & & \\
\hline Artiodactyla (medium) & deer-size artiodactyl & 1 & & & \\
\hline Odocoileus sp. & deer & & 1 & & \\
\hline & TOTAL & 43 & 42 & 49 & 59 \\
\hline
\end{tabular}

\section{Unit 3}

Four levels in Unit 3 had 19 faunal specimens. Five large mammal bones came from Level 2 ( $10-20 \mathrm{~cm}$ bs), and two large mammal bones were recovered from Level 3 (20-30 cm bs). One medium mammal bone, nine large mammal bones, and one medium artiodactyl were found in Level $4(30-40 \mathrm{~cm}$ bs). One medium artiodactyl femur shaft fragment was recovered from $40-50 \mathrm{~cm}$ bs). Twelve specimens from Unit 3 are burned.

\section{Summary}

Four shovel tests and three units in midden deposits at the South Lilly \#4 site (41UR279) yielded 285 faunal specimens, including 193 fragments recovered from fine screen samples taken in two units. Unidentifiable small mammal remains dominate the collection, but this is probably a result of collection bias (i.e., the selective use of finescreening). Unidentifiable large mammal remains are also abundant $(n=72)$.

Animals never supplied more than a subsidiary part of the food supply for the Caddo peoples (e.g., Newcomb 1993). The faunal collection from the South Lilly \#4 site indicates that some of the Caddo diet consisted of large and small game, including deer, probably squirrel and rabbit, supplemented with turtle. The presence of the raccoon may indicate the procurement of animals for hides as well. The faunal assemblage from the site can be considered subsistence debris.

\section{MUSSEL SHELL}

Six fragmentary pieces of freshwater mussel shell $(1.0 \mathrm{~g})$ were recovered in the Caddo midden deposits. These came from $20-30 \mathrm{~cm}$ bs in Units 1 and 2 . 


\section{CONCLUDING COMMENTS}

The South Lilly \#4 site (4IUR279) is a well-preserved prehistoric Caddo habitation site, perhaps a farmstead, on South Lilly Creek. Investigations in 2003 uncovered a midden deposit as well as at least two pit features; possible post hole stains were also noted in sediments beneath the midden itself. One radiocarbon date and a series of OCR dates suggest that the midden accumulated between about AD 1390 and the early part of the $16^{\text {th }}$ century, probably during the early part of the Late Caddoan Titus phase (Perttula 1998).

The midden deposits contain quantities of domestic artifacts, principally including utility ware ceramic sherds, lithic debris from primarily locally procured quartzite, many charred plant remains (especially charred hickory nutshells, processed for their meat and oil), and a high density of animal remains. Species hunted for meat and/or hides included deer, raccoon, and squirrel, and turtles were also apparently eaten by the Caddo inhabitants of the site.

The South Lilly \#4 site holds considerable potential - because of its well-preserved archaeological deposits and features - to better understand, through further research, the life and times of the prehistoric Caddo peoples that lived in this part of northeastern Texas some 400-600 years ago. We hope that further work at the site will allow us to investigate the spatial arrangement and composition of the structures and features created by the families and households that lived here, as well as obtain detailed information on their health and diet, in particular establishing how important cultivated plants (such as maize, beans, and squash) were to the Caddo people at that time. Additional studies of the ceramic and lithic artifacts made and used by the Caddo at the site should offer insights into how plant and animal foods were processed and cooked, where raw materials (both clay and stone) were gathered, and the styles on the decorated vessels may point to the strength of local and community relationships and social entities. There will be more avenues to explore at the site as future archaeological work is planned and eventually completed, but for now we are grateful that the South Lilly \#4 site remains protected and preserved until new archaeological studies of the Caddo people beckon.

\section{ACKNOWLEDGMENTS}

We would like to thank the landowner, Mr. M. G. Drew, for permission to conduct the archaeological investigations at the South Lilly \#4 site, as well as others on his property along South Lilly Creek. Sandra Hannum prepared the maps and profiles in this article.

\section{REFERENCES CITED}

Burt, W. H. and R. P. Grossenheider

1980 A Field Guide to the Mammals. Peterson Field Guide Series, edited by R. T. Peterson. 3rd edition, Houghton Mifflin Co., Boston.

Davis, W. B.

1978 The Mammals of Texas. Bulletin No. 41, revised. Texas Parks and Wildlife Department, Austin.

Gilbert, B. M.

1980 Mammalian Osteology, B. M. Gilbert, Publisher, Laramie. 
Henderson, J.

1978 Faunal Analyses. In Evaluation of the Archaeology at the Proposed Cooper Lake, by K. Doehner, D. Peter, and S. A. Skinner. Research Paper No. 114. Archaeology Research Program, Southern Methodist University, Dallas.

Munzel, S.

1986 Quantitative Analysis and the Reconstruction of Site Patterning. Paper presented at the Vth International Conference of the International Council for ArchaeoZoology, August 25-30, Bordeaux.

Newcomb, W. W., Jr.

I993 The Indians of Texas from Prehistoric to Modern Times. University of Texas Press, Austin.

Olsen, S.J.

1964 Mammal Remains from Archaeological Sites, Part 1: Southeastern and Southwestern United States. Papers (Vol. 56, No. 1) of the Peabody Museum of Archaeology and Ethnology, Harvard University, Cambridge.

Perttula, T. K.

1998 Late Caddoan Societies in the Northeast Texas Pineywoods. In The Native History of the Caddo: Their Place in Southeastern Archeology and Ethnohistory, edited by T. K. Perttula and J. E. Bruseth, pp. 69-90. Studies in Archeology 30. Texas Archeological Research Laboratory, The University of Texas at Austin.

Schmid, E.

1972 Atlas of Animal Bones. Elsevier Publishing, Amsterdam.

Yates, B. C.

1999 Vertebrate Fauna from Hurricane Hill. In The Hurricane Hill Site (41HP106): The Archaeology of a Late Archaic/Early Ceramic and Early-Middle Caddoan Settlement in Northeast Texas, edited by T. K. Perttula, pp. 345-353. 2 Vols. Special Publication No. 4. Friends of Northeast Texas Archaeology, Pittsburg and Austin. 


\title{
CALIBRATION OF RADIOCARBON AGE TO CALENDAR YEARS
}

(V ariables: C $13 / \mathrm{C} 12=-25.2:$ lab. $\mathrm{mult}=1$ )

\section{Laboratory number: Beta-183858}

Conventional radiocarbon age: $\quad 460 \pm 50 \mathrm{BP}$

2 Sigma calibrated result: Cal AD 1410 to 1500 (Cal BP 540 to 450 )

(95\% probability)

\author{
Intercept data
}

Intercept of radiocarbon age

with calibration curve: Cal A D 1440 (Cal BP 510)

1 Sigma calibrated result: CaI A D 1420 to 1460 (Cal B P 530 to 490 )

( $68 \%$ probability)

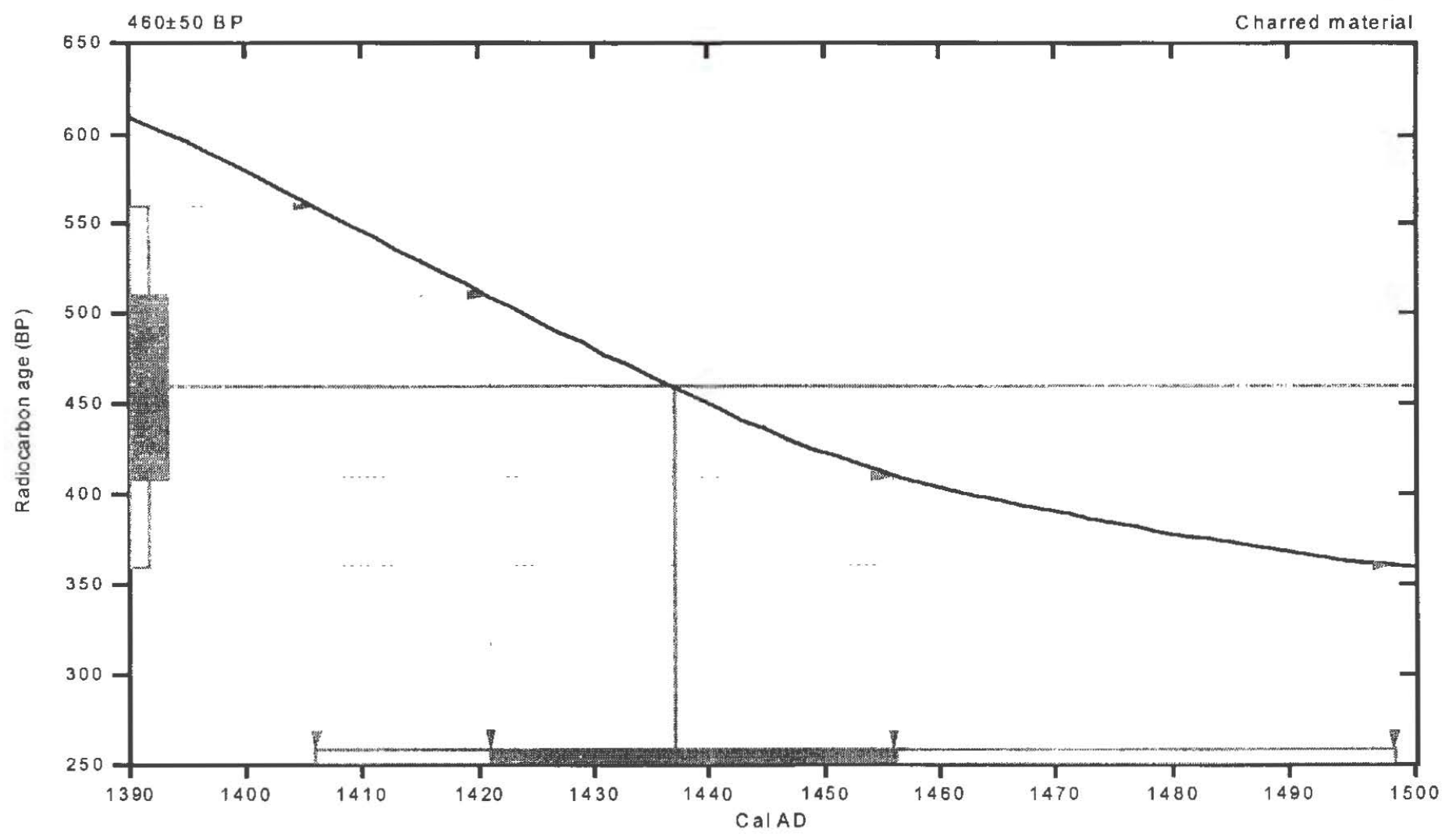

References:

Database used

Calibration Database

Editorial Com ment

Stuiver. M., van der Plicht, H., 1998, Radiocarbon to(3), pxii-xiii

IN TCAL98 Radiocarbon Age Calibration

Siwiver. M., et. al., 1998, Radiucarbon 40(3), p1041-1083

$M$ athematics

A Simplified Approach to Calibrating C14 Dates

Talma, A. S., Vogel, J. C., 1993, Radiocarbon 35(2), p317-322

\section{Beta Analytic Inc.}

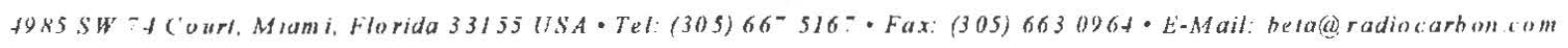




\section{CALIBRATION OF RADIOCARBON AGE TO CALENDAR YEARS}

(V ariables: $\mathrm{C} 13 / \mathrm{C} 12=-25.4: \mathrm{lab} . \mathrm{mult}=1$ )

Laboratory number: Beta-183859

Conventional radiocarbon age: $860 \pm 70 \mathrm{BP}$

2 Sigma calibrated result: Cal AD 1020 to 1280 (Cal BP 930 to 670)

$(95 \%$ probability)

1ntercept data

1ntercept of radiocarbon age with calibration curve:

Cal AD $1190($ Cal BP 760)

1 Sigma calibrated results: Cal A D 1050 to 1100 (Cal B P 900 to 850 ) and (68\% probability) Cal AD 1140 to 1260 (Cal B P 810 to 690$)$

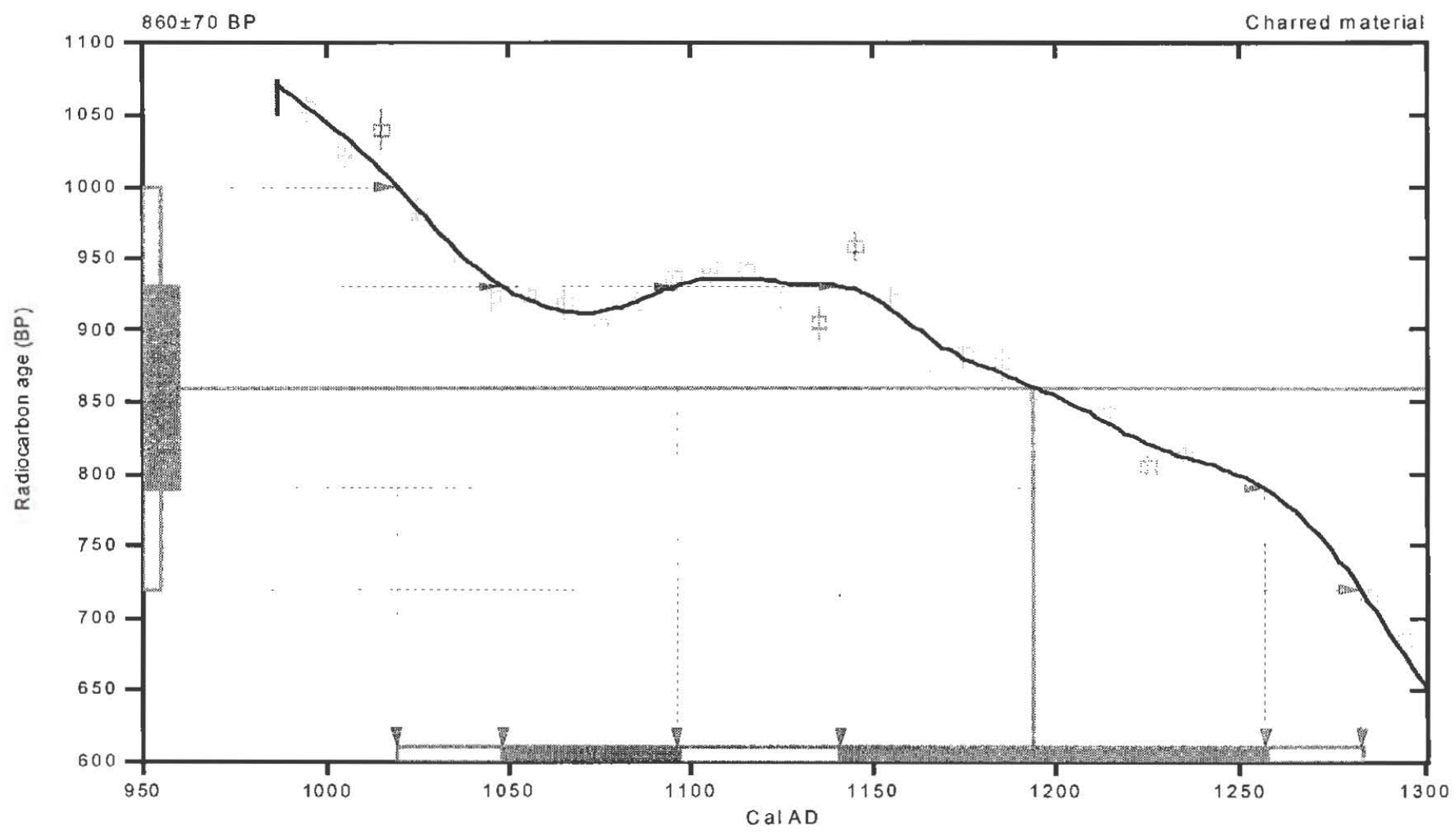

Re ferences:

Database used

Calibration Database

Editorial Com ment



INTCA L98 Radiocarbon Age Calthration

Stuiver, M., et. al., 1998, Radiocarbon 40(3), p1041-1083

$M$ ath em atics

A Simplified Approach to Calibrating CI4 Dates

Talma, A.S., Vogel, J. C., I993, Radiocarbon 35(2), p317-322

\section{Beta Analytic Inc.}

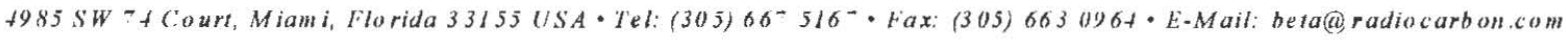


APPENDIX 2,

OCR DATA FORMS FOR 41 UR279 


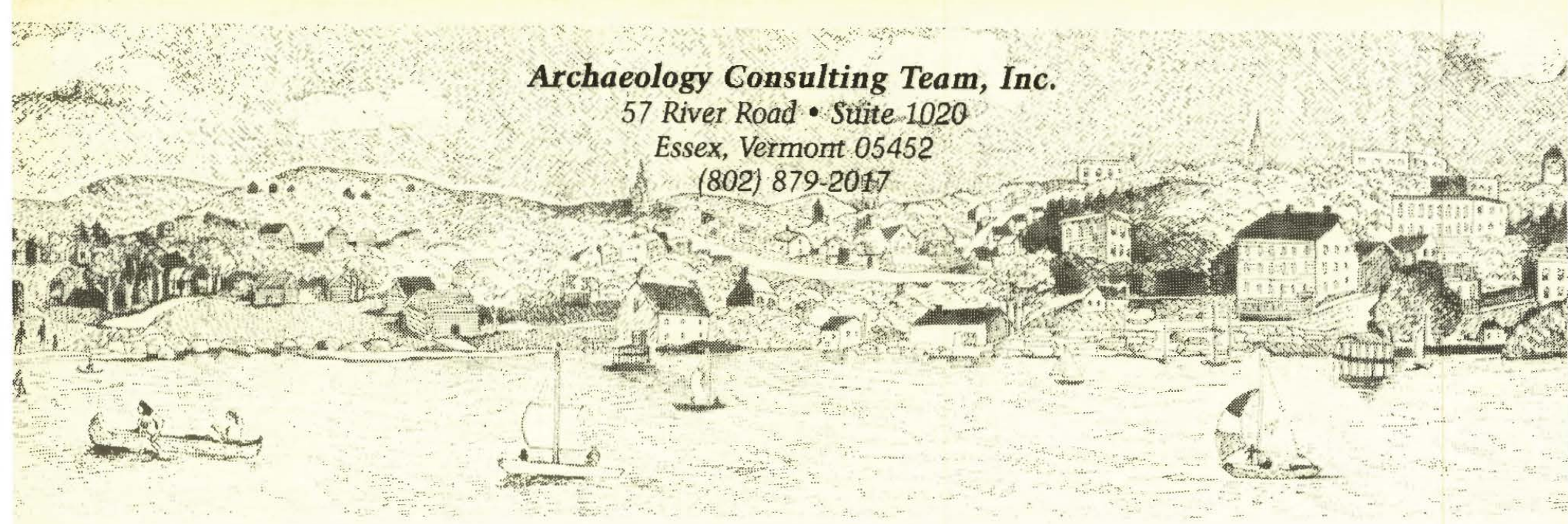

March 14, 2003

Dr. Timothy Perttula

Archaeological \& Environmental Consultants, LLC

10101 Woodhaven Drive

Austin, TX 78753

Dear Dr. Perttula:

Thank you for sending us the additional soil samples from South Lilly \#4 for OCR $R_{\text {DATE }}$ analyses. These samples were received on February 18, 2003, in good condition. Prior to our analyses, we screened the samples through a $2 \mathrm{~mm}$ meshed screen to remove any cultural material. The coarse fraction found in these samples is being returned to you for further study. The OCR $R_{\text {DATE }}$ analyses were conducted in accordance with the procedures outlined in:

Frink, D.

1992 The Chemical Variability of Carbonized Organic Matter Through Time. Archaeology of Eastern North America, Vol. 20:67-79.

using the data format and formula as presented in:

Frink, D.

1994 The Oxidizable Carbon Ratio (OCR): A Proposed Solution to Some of the Problems Encountered with Radiocarbon Data. North American Archaeologist. Vol.15 (\#1). 
The results of the OCR analyses for your samples are presented on the separate computer printouts. The bottom line OCR $\mathrm{DATE}_{\mathrm{DT}}$ and the confidence interval have been rounded to the nearest year. Also, the expression of results has been adjusted to "years before present"- -defined as 1950, to correspond with calibrated ${ }^{14} \mathrm{C}$ radiocarbon data. For example, your sample \#2 (ACT \#6396) should read OCR DATE: $555 \pm 16$ YBP. Further rounding may be prudent - i.e. $550 \pm 20$ YBP.

Please note, that in addition to the individual data printouts, we have provided data tables for the column. The highlighted data set represent significant pedologic events of stability. These might be natural, environmental, cultural, or a combination of any of these events. The intent to suggest contextual data within which your artifactual material may be interpreted.

I hope that the OCR site. If you have further questions on the OCR procedure, please don't hesitate to give us a call. To aid us in improving this dating technique, we would appreciate it if you would send us information on how the OCR DATE corresponds to other data classes for these samples.

Also please feel free to keep track of the OCR literature and data on our WEBSite:

http://members.aol.com/dsfrink/ocr/ocrpage.htm

Sincerely,

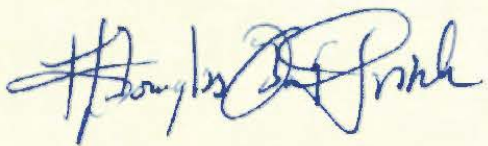

Douglas S. Frink 


\section{Calculated OCR DATE Report}

For Archeological \& Environmental C

13-Mar-03

\begin{tabular}{|c|c|c|}
\hline Sample Id: & ACT \# 6395 & \\
\hline Site Id \#: & South Lilly \#4 & \\
\hline Location: & $a$ & \\
\hline Feature Type: & Cultural & \\
\hline Feature Designation: & 1 & \\
\hline Sample Recieved: & $2 / 18 / 2003$ & \\
\hline Calculated OCR DATE: & 409 YBP (1950) & $+1-12$ \\
\hline
\end{tabular}



Oxidizable Carbon Ratio

\begin{tabular}{|c|c|c|}
\hline Sample Id: & ACT \# 6396 & \\
\hline Site Id \#: & South Lilly \#4 & \\
\hline Location: & a & \\
\hline Feature Type: & Cultural & \\
\hline Feature Designation: & 2 & \\
\hline Sample Recieved: & $2 / 18 / 2003$ & \\
\hline Calculated OCR DATE: & 555 YBP(1950) & $+1-16$ \\
\hline
\end{tabular}

\begin{tabular}{|r|r|r|}
\hline Sample Id: & ACT \#6397 \\
\hline Site Id \#: & South Lilly \#4 \\
\hline Location: & Cultural \\
\hline Feature Type: & 3 \\
\hline Feature Designation: & $2 / 18 / 2003$ \\
\hline Sample Recieved: & 542 & YBP $(1950)$ \\
\hline Calculated OCR DATE: & $+/-16$ \\
\hline
\end{tabular}

\begin{tabular}{|c|c|c|}
\hline Sample Id: & ACT \# 6398 & \\
\hline Site Id \#: & South Lilly \#4 & \\
\hline Location: & $a$ & \\
\hline Feature Type: & Cultural & \\
\hline Feature Designation: & 3 & \\
\hline Sample Recieved: & $2 / 18 / 2003$ & \\
\hline Calculated OCR DATE: & $658|Y B P(1950)|$ & $+/-19$ \\
\hline
\end{tabular}


Calculated OCR DATE Report

For Archeological \& Environmental C

13-Mar-03

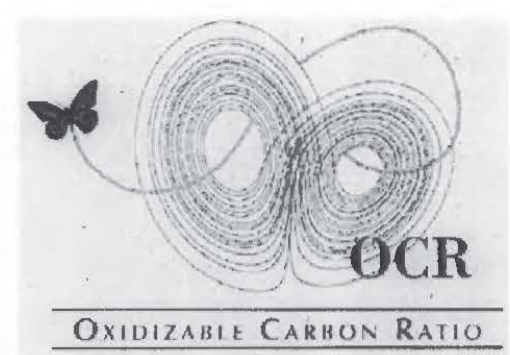

\begin{tabular}{|r|r|}
\hline Sample Id: & ACT \# 6399 \\
\hline Site Id \#: & South Lilly \#4 \\
\hline Location: & Cultural \\
\hline Feature Type: & 5 \\
\hline Feature Designation: & $2 / 18 / 2003$ \\
\hline Sample Recieved: & 709 \\
\hline Calculated OCR DATE: & $+1950)$ \\
\hline
\end{tabular}


South Lilly \#4

\begin{tabular}{|c|c|c|c|c|c|c|c|c|c|c|c|c|c|c|}
\hline \begin{tabular}{|c|} 
Soil \\
Depth
\end{tabular} & $\mathrm{pH}$ & \begin{tabular}{|c|}
$\%$ \\
Organic \\
Carbon \\
(LOI)
\end{tabular} & $\begin{array}{l}\text { Ocr } \\
\text { Date }\end{array}$ & \begin{tabular}{|l|} 
Very \\
Coarse
\end{tabular} & Coarse & Medium & Fine & $\begin{array}{l}\text { Very } \\
\text { Fine }\end{array}$ & $\begin{array}{c}\text { Coarse } \\
\text { Silt }\end{array}$ & $\begin{array}{c}\text { Fine } \\
\text { Silt }\end{array}$ & \begin{tabular}{|c|} 
Sample \\
Id
\end{tabular} & $\begin{array}{c}\% \\
\text { Oxidizable } \\
\text { Carbon } \\
\text { (WB) }\end{array}$ & $\begin{array}{l}\text { OCR } \\
\text { Ratio }\end{array}$ & $\mathrm{Mn}$ \\
\hline 9 & 4.4 & 1.413 & 409 & .089 & .141 & 634 & 7.425 & 29.674 & 37.979 & 24.057 & 6395 & 0.49 & 2.88 & 36.1 \\
\hline 19 & 4.6 & 1.186 & 555 & 149 & 186 & 678 & 7,225 & 29.964 & 36.097 & 25721 & 6396 & 0.41 & 2.89 & 25.1 \\
\hline 29 & 5.0 & 0.87 & 542 & .023 & .103 & .897 & 7.215 & 28.091 & 38.085 & 25.586 & 6397 & 0.36 & 2.42 & 17.1 \\
\hline 39 & 5.3 & 0.65 & 658 & .097 & .118 & .907 & 7.068 & 30.934 & 35.273 & 25.603 & 6398 & 0.33 & 1.97 & 13.475 \\
\hline 54 & 5.9 & 0.378 & 709 & . & .033 & .574 & 6.835 & 27.348 & 34.538 & 30.671 & 6399 & 0.19 & 1.99 & 10.85 \\
\hline
\end{tabular}


APPENDIX 3,

FAUNAL INVENTORY, 41UR279 


\begin{tabular}{|c|c|c|c|c|c|c|c|c|c|c|c|c|}
\hline Table 1 & Complete & Inven & tory of DSL & \#4 Faunal S & Sample & & & & & & & \\
\hline Unit & Depth & Qty & Taxon & Elem/Por & Side & Age & Taphonom & Burn & Gnaw & Mod & Wt/g & Comments \\
\hline ST 1 & 20 to 40 & 1 & lg mam & I.b.frag & & & absent & wh & & & 0.2 & \\
\hline ST 2 & 70 & 1 & med art & mtpod prox & post & & exfol & not & & & 3.1 & spir frac \\
\hline ST 2 & 70 & 1 & med art & mtpod dist & & & absent & not & rodent & & 8.2 & spir frac \\
\hline ST 2 & 20 to 40 & 1 & deer & tooth frg & & & absent & not & & & 0.05 & \\
\hline ST 2 & 20 to 40 & 1 & Ig mam & l.b.frag & & & absent & wh & & & 0.1 & \\
\hline ST 4 & Oto20 & 1 & lg mam & I.b.frag & & & absent & blk & & & 0.9 & spir frac \\
\hline ST 4 & Oto20 & 1. & Ig mam & 1.b.frag & & & absent & wh & & & 0.2 & \\
\hline ST 4 & 20 to 40 & 1 & deer & tooth frg & & & absent & not & & & 0.5 & \\
\hline ST 4 & 20 to 40 & 1 & lg mam & unid & & & absent & wh & & & 0.1 & \\
\hline ST 4 & 40 to60 & 1 & sm mam & I.b.frag & & & absent & wh & & & 0.1 & \\
\hline ST 5 & Oto20 & 1 . & mammal & unid & & & absent & wh & & & 0.1 & \\
\hline ST 5 & 20 to 40 & 1 & Ig mam & I.b.frag & & & absent & wh & & & 0.3 & \\
\hline ST 5 & 20 to 40 & 1 & Ig mam & unid & & & absent & wh & & & 0.2 & \\
\hline U 1 & Oto10 & 1 & Ig mam & I.b.frag & & & absent & blk & & & 1.2 & spir frac \\
\hline U 1 & Oto10 & 1 & lg mam & l.b.frag & & & absent & wh & & & 0.3 & spir frac \\
\hline U 1 & 10 to 20 & 3 & Ig mam & I.b.frag & & & absent & wh & & & 0.8 & \\
\hline U 1 & 10 to 20 & 2 & Ig mam & unid & & & exfol & not & & & 0.5 & \\
\hline U 1 & 10 to 20 & 1 & Ig mam & vert epiph $f$ & & imm & absent & not & & & 0.1 & \\
\hline U 1 & 10 to 20 & 6 & mammal & unid & & & abrade & wh & & & 0.2 & \\
\hline U 1 & 10 to 20 & 1 . & med art & mtpod shft & & & absent & wh & & & 0.4 & \\
\hline U 1 & 20 to 30 & 1 & deer & tooth frg & & & absent & char & & & 0.05 & \\
\hline U 1 & 20 to 30 & 1 & Ig mam & I.b.frag & & & absent & blk & & & 0.2 & spir frac \\
\hline U 1 & 20 to 30 & 1. & Ig mam & unid & & & absent & blk & & & 0.2 & \\
\hline U 1 & 20 to 30 & 1 & Ig mam & unid & & & absent & char & & & 0.2 & \\
\hline U 1 & 20 to 30 & 3 & lg mam & unid & & & abrade & wh & & & 0.6 & \\
\hline U 1 & 20 to 30 & 1. & lg mam & I.b.frag & & & absent & wh & & & 0.4 & spir frac \\
\hline U 1 & 20 to 30 & 1 & lg mam & unid & & & abrade & not & & & 0.1 & \\
\hline U 1 & 20 to 30 & 1 & lg mam & I.b.frag & & & absent & not & rodent & & 1 & spir frac \\
\hline U 1 & 20 to 30 & 4 & Ig mam & unid & & & absent & not & & & 0.5 & \\
\hline U 1 & 20 to 30 & 1 & med art & rad prox frs & & & absent & not & rodent & & 7 & spir frac \\
\hline U 1 & 20 to 30 & 1 & med mam & unid & & & absent & blk & & & 0.3 & \\
\hline U 1 & 20 to 30 & 1 . & med mam & unid & & & absent & wh & & & 0.2 & \\
\hline U 1 & 30 to 40 & 1 & lg mam & unid & & & abrade & wh & & & 0.1 & \\
\hline U 1 & 30 to 40 & 1 & lg mam & I.b.frag & & & absent & wh & & & 0.2 & \\
\hline $\mathrm{U} 1 \mathrm{~F} 1$ & top to 54 & 1 & med art & phx 3 prox & L & & absent & blk & & & 1 & in 2 frgs \\
\hline U $1 \mathrm{FS}$ & 20 to 30 & 1 & med art & mtpod shft & frg & & absent & blk & & & 1.1 & spir frac \\
\hline U $1 \mathrm{FS}$ & 20 to 30 & 1 & med mam & unid & & & absent & blk & & & 0.1 & \\
\hline $\mathrm{U} 1 \mathrm{FS}$ & 20 to 30 & 2 & med mam & tooth frg & & & absent & blk & & & 0.1 & \\
\hline U $1 \mathrm{FS}$ & 20 to 30 & 2 & med mam & 1.b.frag & & & absent & wh & & & 0.4 & \\
\hline U $1 \mathrm{FS}$ & 20 to 30 & 3 & med mam & unid & & & absent & wh & & & 0.1 & \\
\hline U $1 \mathrm{FS}$ & 20 to 30 & 19 & sm mam & unid & & & absent & wh & & & 0.4 & \\
\hline U $1 \mathrm{FS}$ & 20 to 30 & 2 & turtle & shell frg & & & absent & wh & & & 0.05 & \\
\hline U $1 \mathrm{FS}$ & 20 to30 & 2 & unid & unid & & & absent & wh & & & 0.01 & \\
\hline U $1 \mathrm{FS}$ & 20 to 30 & 11. & unid & unid & & & absent & wh & & & 0.1 & \\
\hline U $1 \mathrm{FS}$ & 30 to 40 & 1 & deer & tooth frg & & & absent & not & & & 0.05 & \\
\hline U $1 \mathrm{FS}$ & 30 to 40 & 2 & Ig mam & unid & & & absent & wh & & & 0.1 & \\
\hline U $1 \mathrm{FS}$ & 30 to 40 & 1 & Ig mam & I.b.frag & & & absent & not & & & 0.6 & spir frac \\
\hline U $1 \mathrm{FS}$ & 30 to 40 & 3 & med mam & unid & & & absent & wh & & & 0.1 & \\
\hline U $1 \mathrm{FS}$ & 30 to 40 & 1 & raccoon & PM2 lo & $L$ & & absent & not & & & 0.1 & \\
\hline
\end{tabular}




\begin{tabular}{|c|c|c|c|c|c|c|c|c|c|}
\hline U1FS & 30 to 40 & $1 \mathrm{sm}$ mam & I.b.frag & & absent & blk & & 0.1 & \\
\hline U $1 \mathrm{FS}$ & 30 to 40 & $1 \mathrm{sm}$ mam & I.b.frag & & absent & wh & & 0.2 & \\
\hline $\mathrm{U} 1 \mathrm{FS}$ & 30 to 40 & $16 \mathrm{sm}$ mam & unid & & absent & wh & & 0.2 & \\
\hline U $1 \mathrm{FS}$ & 30 to 40 & 1 turtle & shell frg & & absent & wh & & 0.01 & \\
\hline U $1 \mathrm{FS}$ & 30 to 40 & 14 unid & unid & & absent & wh & & 0.1 & \\
\hline U $1 \mathrm{FS}$ & 30 to 40 & 1 unid & 1.b.frag & & exfol & not & & 0.3 & poss bird \\
\hline U 2 & 46 & 2 lg mam & unid & & exfol & not & & 0.2 & nwcorn fl scrp \\
\hline U 2 & 10 to 20 & $3 \mathrm{lg}$ mam & I.b.frag & & absent & wh & & 0.7 & \\
\hline U 2 & 10 to 20 & $1 \mathrm{lg}$ mam & unid & & absent & wh & & 0.3 & \\
\hline U 2 & 20 to 30 & 2 lg mam & I.b.frag & & absent & blk & & 0.6 & \\
\hline U 2 & 20 to 30 & $8 \mathrm{lg}$ mam & unid & & abrade & wh & & 1.2 & \\
\hline U 2 & 20 to 30 & $1 \mathrm{lg}$ mam & I.b.frag & & absent & wh & & 0.9 & spir frac \\
\hline U 2 & 20 to 30 & 1 turtle & shell frg & & absent & wh & & 0.05 & \\
\hline U 2 & 30 to 40 & $4 \mathrm{lg}$ mam & unid & & exfol & not & & 0.9 & \\
\hline U 2 & 30 to 40 & 1 med art & cran frg & L & exfol & char & & 2.5 & below petrous \\
\hline U 2 & 30 to 40 & 2 med mam & unid & & absent & wh & & 0.4 & \\
\hline U 2 FS & 20to30 & $1 \mathrm{lg}$ mam & I.b.frag & & absent & wh & & 0.4 & spir frac \\
\hline U 2 FS & 20 to 30 & 1 med mam & mand frg & & exfol & blk & & 0.6 & poss coon \\
\hline U 2 FS & 20 to 30 & 2 med mam & unid & & absent & wh & & 0.1 & \\
\hline U 2 FS & 20 to 30 & $39 \mathrm{sm}$ mam & unid & & absent & wh & & 0.5 & \\
\hline U 2 FS & 20 to 30 & $1 \mathrm{sm}$ mam & unid & & exfol & not & & 0.05 & \\
\hline U 2 FS & 20 to 30 & 5 unid & unid & & absent & wh & & 0.1 & \\
\hline U 2 FS & 30 to 40 & $1 \mathrm{lg}$ mam & I.b.frag & & absent & blk & & 0.2 & spir frac \\
\hline U 2 FS & 30 to 40 & 6 med mam & unid & & absent & wh & & 0.2 & \\
\hline U $2 \mathrm{FS}$ & 30 to 40 & $1 \mathrm{sm}$ mam & I.b.frag & & absent & wh & & 0.1 & \\
\hline U 2 FS & 30 to 40 & $41 \mathrm{sm}$ mam & unid & & absent & wh & & 0.3 & \\
\hline U 2 FS & 30 to 40 & $1 \mathrm{sm}$ mam & unid & & absent & not & & 0.01 & \\
\hline U 2 FS & 30 to 40 & 9 unid & unid & & absent & wh & & 0.1 & \\
\hline U 3 & 10 to 20 & $1 \mathrm{lg}$ mam & unid & & abrade,exf & blk & & 2.4 & spir frac \\
\hline U 3 & 10 to 20 & $1 \mathrm{lg}$ mam & I.b.frag & & absent & blk & & 0.5 & spir frac \\
\hline U 3 & 10 to 20 & 2 lg mam & unid & & abrade & wh & & 0.3 & \\
\hline U 3 & 10 to 20 & $1 \mathrm{lg}$ mam & alveolar frg & & exfol & wh & & 0.2 & \\
\hline U 3 & 20 to 30 & $2 \mathrm{lg}$ mam & l.b.frag & & absent & blk & & 0.6 & \\
\hline U 3 & 30 to 40 & 2 lg mam & unid & & abrade & wh & & 0.4 & \\
\hline U 3 & 30 to 40 & $1 \mathrm{lg}$ mam & unid & & abrade,exf & not & & 0.6 & \\
\hline U 3 & 30 to 40 & $6 \mathrm{lg}$ mam & unid & & exfol & not & & 0.3 & \\
\hline U 3 & 30 to 40 & 1 med art & calc prox & L & abrade,exf & char & carn & 5 & \\
\hline U 3 & 30 to 40 & 1 med mam & unid & & exfol & blk & & 0.2 & \\
\hline U 3 & 40 to 50 & 1 med art & fem shft frg & & absent & blk & & 3.1 & spir frac \\
\hline
\end{tabular}

